A. M. Ahmed et al, Static Behaviour of Different Types of R.C Beam-Column Connections as Affected by Both Value of Acting Axial Normal Force and Grade of Used Concrete (Theoretical Study) , pp. 321- 364

\title{
STATIC BEHAVIOUR OF DIFFERENT TYPES OF R.C BEAM- COLUMN CONNECTIONS AS AFFECTED BY BOTH VALUE OF ACTING AXIAL NORMAL FORCE AND GRADE OF USED CONCRETE (THEORETICAL STUDY)
}

\author{
Abdel Rahman M. Ahmed ${ }^{1}$, Mohamed M. Rashwan ${ }^{2}$ and \\ Lamiaa K. Idriss ${ }^{3 \text {, * }}$ \\ Staff in Civil Engineering Department, Faculty of Engineering, Assiut University \\ Received 11 November 2012; accepted 30 November 2012
}

\begin{abstract}
This paper describes a theoretical study of the effect of both acting axial loads and grade of concrete on the static behaviour of (32) thirty two Reinforced Concrete (RC) Beam-column joints. ABAQUS\CAE version 6.7, a nonlinear finite element analysis software package, was developed specifically for the analysis of reinforced concrete structures under plane stress conditions. Variable axial loads were applied and increased gradually with constant lateral load, which was applied maintaining at the top of the column at internal and external beam-column joint only the ultimate and cracking axial loads were recorded as well as the corresponding versus vertical displacement, the maximum joint shear stresses, axial, stresses strains, and absorbed energy, mode of failure using different grades of concrete C250, C400, C600 and C1200 were evaluated and recorded.
\end{abstract}

Keywords: Column axial load, RC beam column connection, energy absorption, ABAQUS $\backslash$ CAE, concrete compressive strength, shear stress, ultimate, cracking load and energy absorption.

\section{Introduction}

Chris P. et al., (2002); suggests limiting experimental evidence that increasing the column axial load tends to reduce the total lateral drift at yield (Kurose 1987). Although some researchers reported that increasing column axial load results in increasing shear strength of joints without reinforcement, the data do not show a significant trend (Beres et al., 1992). Because of the binding of the profile steel and stirrups, the axial pressure makes the concrete of the core area in the three dimensions, stress state which inhibits the cracking of concrete. Also, after the cracking of concrete, the axial pressure makes the larger mechanical friction formed between the concrete blocks, so that a moderate axial compression ratio can enhance the shear strength of the joints. However, if the axial pressure exceeds the critical value, the concrete will be crushed, and the shear strength will be reduced (Xiaoli Yang 2009). Bing Li, et al., (2003), have already investigated the influence of axial loading on the seismic behavior of beam- wide column joints, it can be seen that when axial load increased from 0 to $0.2 f_{c}^{\prime} A_{g}$ the number of cycles increased correspondingly so the joints without transverse reinforcement are easily overloaded and failed at an earlier ductility level stage.

The ultimate load obtained and suggested by BS8110 for interior joint is given by following Equation:

$$
\mathrm{Nu}=0.45 f_{\mathrm{cu}} \mathrm{A}_{\mathrm{c}}+0.95 f^{\prime}{ }_{\mathrm{y}} \mathrm{A}_{\mathrm{st}}
$$

* Corresponding author.

Civil Engineering Department, Faculty of Engineering, Assiut University 
A. M. Ahmed et al, Static Behaviour of Different types of R.C Beam-Column Connections as Affected by Both Value of Acting Axial Normal Force and Grade of Used Concrete (Theoretical Study), pp. 321- 364

Kumar et. al., ( 2002) found that both the joint rotation and the axial load in the column increase the ductility and energy dissipation capacity and reduced the joint region damage (Xiaoli Yang 2009). Changing cross section of columns, the eccentric axial force forms, which will cause the stress of the joint area to superimpose. The stiffness, ductility and the energy dissipation performance of the overall joint will be decreased with the increase of eccentric bending moment.

More recently (S. R. Uma 2006), have shown the effect of axial load on nominal shear stress. In recent research publications (Hakuto et al., 2000) the significance of representing joint capacity in terms of principal stresses has been discussed, which recognizes the axial load acting on the column. A critical situation where the axial load on the column is very large, diagonal compression failure of strut occurring before the first diagonal tensile cracking in the joint has been cautioned. Therefore, it is very essential to account for the axial load effect in limiting the joint nominal shear stress. Paul S. et al., (2000) study; the effect of the column load on ultimate capacity, with the axial load shown as an approximate equivalent concrete stress by simply dividing by the area of the column. For all arrangements increasing the column load, up to a value of approximately $20 \mathrm{MPa}$, increases the ultimate capacity of the joint. At column loads above $20 \mathrm{MPa}\left(1 / 3 f_{c u}\right)$, the combined stresses reduce the ultimate capacity of the joint.

Increasing the column load stiffens of the joint and improves the effectiveness of the anchorage transfer along the initial part of the reinforcing bar by pinching the bar. The increase in the ultimate capacity of the joint is due to the higher stiffness compares the code provisions for nominal shear stress for varying axial load ratios for both interior and exterior joints. It can be seen that ACI318M-(2002) code allows higher nominal shear stress and NZS 3101 (1995) code limits to a lesser value, and both are not affected by axial loads. On the other hand, limiting value of nominal shear stress as per EN3101 (1995) code decreases as the axial load increases, especially for exterior joints, where the variation of axial loads acting on the column could be high during seismic event.

To investigate and compare the behaviors of joint specimens with the proposed detail on 32 joints, the normal-strength and high-strength test specimens are both representative of an interior, and exterior joint specimens with constant lateral load, variable compressive axial load at the top of the column were applied until it failed for the purposed of studying cracking, ultimate axial load, the maximum joint shear stresses and total absorbed energy for different grades of concrete C250, C400, C600, and C1200.

\section{Details of RC joints}

Table 1 includes the data of the connection between the main beam, column, and slab. Thirty two (32) Joints were taken into account. Beam size for all joints of $\left(b_{b} \times d_{b}\right) \mathrm{mm}$ is (250 $\mathrm{mm}$ wide by $300 \mathrm{~mm}$ deep) $\mathrm{mm}$ as well as column size of $\left(b_{c} \times \mathrm{d}_{\mathrm{c}}\right) \mathrm{mm}$ is $(300 \times 300$ $\mathrm{mm})$ were kept constant.

The total height of the columns above and below the joint was the same for both specimens at $\mathrm{H}=2.0 \mathrm{~m}$, length of beam right and left the joint $\mathrm{L}=3.0 \mathrm{~m}$, which gave $\mathrm{L} / 2=1.5$ $\mathrm{m}$. The floor slabs for both specimens were of equal sizes, with a thickness ts of $120 \mathrm{~mm}$.

Journal of Engineering Sciences, Assiut University, Faculty of Engineering, Vol. 41, No. 2, March, 2013, E-mail address: jes@aun.edu.eg 
A. M. Ahmed et al, Static Behaviour of Different types of R.C Beam-Column Connections as Affected by Both Value of Acting Axial Normal Force and Grade of Used Concrete (Theoretical Study), pp. 321- 364

The boundary conditions, beam ends were supported by horizontal rollers, while the bottom of the column was supported by a mechanical hinge constant too, All the joints were chosen to have concrete of specified characteristic cube strength $\left(f_{\mathrm{c}}^{\prime}\right)$, of 250-400$600-1200 \mathrm{~kg} / \mathrm{cm}^{2}$, and yield stress for reinforcing bar $\left(f_{\mathrm{y}}\right) 2400-2800-3600-4000 \mathrm{~kg} / \mathrm{cm}^{2}$ respectively.

The reinforcement details of all the specimens were identical as shown in Fig. 1.a for interior joint, and Figure 1.b for exterior joint, where the beam was equally reinforced at the top and bottom by four high-yield deformed bars of $16 \mathrm{~mm}$ diameter $\mathrm{A}_{\mathrm{bs}}$ (i.e. $4 \Phi 16$, 4Ф16).

Stirrups $\left(\rho_{\mathrm{w}}\right)$ from $6 \mathrm{~mm}$-diameter mild steel, bars with specified characteristic yield strength of $2400 \mathrm{~kg} / \mathrm{cm}^{2}$ were provided at $80 \mathrm{~mm}$ spacing (i.e. Ф6@80 stirrups). The column contained $\left(A_{c s}\right) 12 \Phi 16$ longitudinal reinforcing bars distributed around the perimeter. The transverse reinforcement in the column comprised $\Phi 6$ square hoops and $\Phi 6$ cross ties in two perpendicular directions at $80 \mathrm{~mm}$ spacing, as shown in Table 1 and Fig.1.

\section{Mesh arrangement:}

The mesh module allows to generate meshes at Fig.2 on assemblies created with ABAQUSICAE various levels of automation and control are available so that you can create a mesh that meets the needs of your analysis. Mesh refinement is required. When severely nonlinear material Models are used, however, increasing the number of element can increasing constrains within the model. This reduces hear deformation that can lead to an overlay stiff load deflection response (Abaqus. 2000).

\section{Boundary conditions and applied loadings:}

The loadings set up are shown in Figures 3.a, 3.b, for interior and exterior joint. The specimens were supported in vertical position. Statically cyclic lateral load was applied maintaining variable axial load at the top of the column for interior and exterior joint only so as knee joint has no axial load. The top of the column was loaded by two actuators in vertical and horizontal directions. The beam ends were supported by horizontal rollers, while the bottom of the column was supported by a mechanical hinge. The distances between two loading points for beams and columns are shown in Fig. 3.

Journal of Engineering Sciences, Assiut University, Faculty of Engineering, Vol. 41, No. 2, March, 2013, E-mail address:jes@aun.edu.eg 
A. M. Ahmed et al, Static Behaviour of Different types of R.C Beam-Column Connections as Affected by Both Value of Acting Axial Normal Force and Grade of Used Concrete (Theoretical Study), pp. 321- 364

\section{Table 1}

Properties of joints.

\section{Type of beam-column joints}

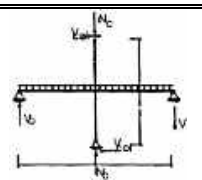

Interior joint

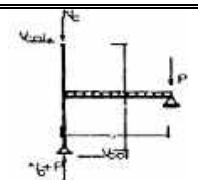

Exterior joint

(a) Beam $\left(b_{b} \times d_{b}\right) m m$

Top bars

$\mathrm{a}_{\mathrm{t}} \mathrm{mm}^{2}$

$(250 \times 300)$

$(250 \times 300)$

$\mathrm{p}_{\mathrm{t}} \%$

$4 \Phi 16$

804

$4 \Phi 16$

1.18

804

Bot. bars

$4 \Phi 16$

804

1.18

$\mathrm{a}_{\mathrm{t}} \mathrm{mm}^{2}$

1.18

$4 \Phi 16$

$\rho_{t} \%$

$2 \Phi 6$

80

804

Stirrups

@ (mm)

0.64

1.18

$\rho_{\mathrm{w}} \%$

$(300 \times 300)$

$12 \Phi 16$

$2 \Phi 6$

(b) column $\left(b_{c} \times d_{c}\right) \mathrm{mm}$

Total Bars

$\mathrm{a}_{\mathrm{g}} \mathrm{mm}^{2}$

2412

2.62

80

$2 \Phi 6$

80

0.64

0.27

$(300 \times 300)$

$12 \Phi 16$

2412

2.62

Hoops

@ (mm)

$\rho_{\mathrm{w}} \%$

(c) connection $\mathrm{H} \times \mathrm{L} \mathrm{mm}$

$(2000 \times 3000)$

2Ф6

3 @ 60

192

$2 \Phi 6$

80

0.27

Hoops

Sets

aw $\mathrm{mm}^{2}$

0.38

Closed

12

$(2000 \times 1500)$

$2 \Phi 6$

3 @ 60

192

0.38

$\rho_{\mathrm{w}} \%$

$4 \Phi 8$

100

Closed

(d) Slabs thick

Longitudinal Dir

@ (mm)

0.38

Transverse Dir.

$24 \Phi 8$

200

0.27

12

$24 \Phi 8$

100

0.38

$24 \Phi 8$

200

Stirrups ratio \%

Note: $\mathrm{a}_{\mathrm{t}}$ : total area of tensile reinforcement, $\rho_{\mathrm{t}}$ : tensile reinforcement ratio, $\mathrm{a}_{\mathrm{g}}$ : total area of longitudinal reinforcement, $\rho_{\mathrm{g}}$ : gross reinforcement ratio, $\mathrm{a}_{\mathrm{w}}$ : total area of web reinforcement placed between top and bottom beam bars, $\rho_{\mathrm{w}}$ : web reinforcement ratio, $\mathrm{Ec}=14000 \sqrt{ } f^{\prime}{ }_{\mathrm{c}} \mathrm{kg} / \mathrm{cm}^{2}, \mathrm{Es}=2.2 \times 10^{6} \mathrm{~kg} / \mathrm{cm}^{2} f_{\mathrm{y}}$ : yield strength, $f^{\prime}{ }_{\mathrm{c}}$ : concrete compressive strength, $f_{\mathrm{t}}^{\prime}$ : concrete tensile strength.

Journal of Engineering Sciences, Assiut University, Faculty of Engineering, Vol. 41, No. 2, March, 2013,E-mail address:jes@aun.edu.eg 
A. M. Ahmed et al, Static Behaviour of Different types of R.C Beam-Column Connections as Affected by Both Value of Acting Axial Normal Force and Grade of Used Concrete (Theoretical Study), pp. $321-364$

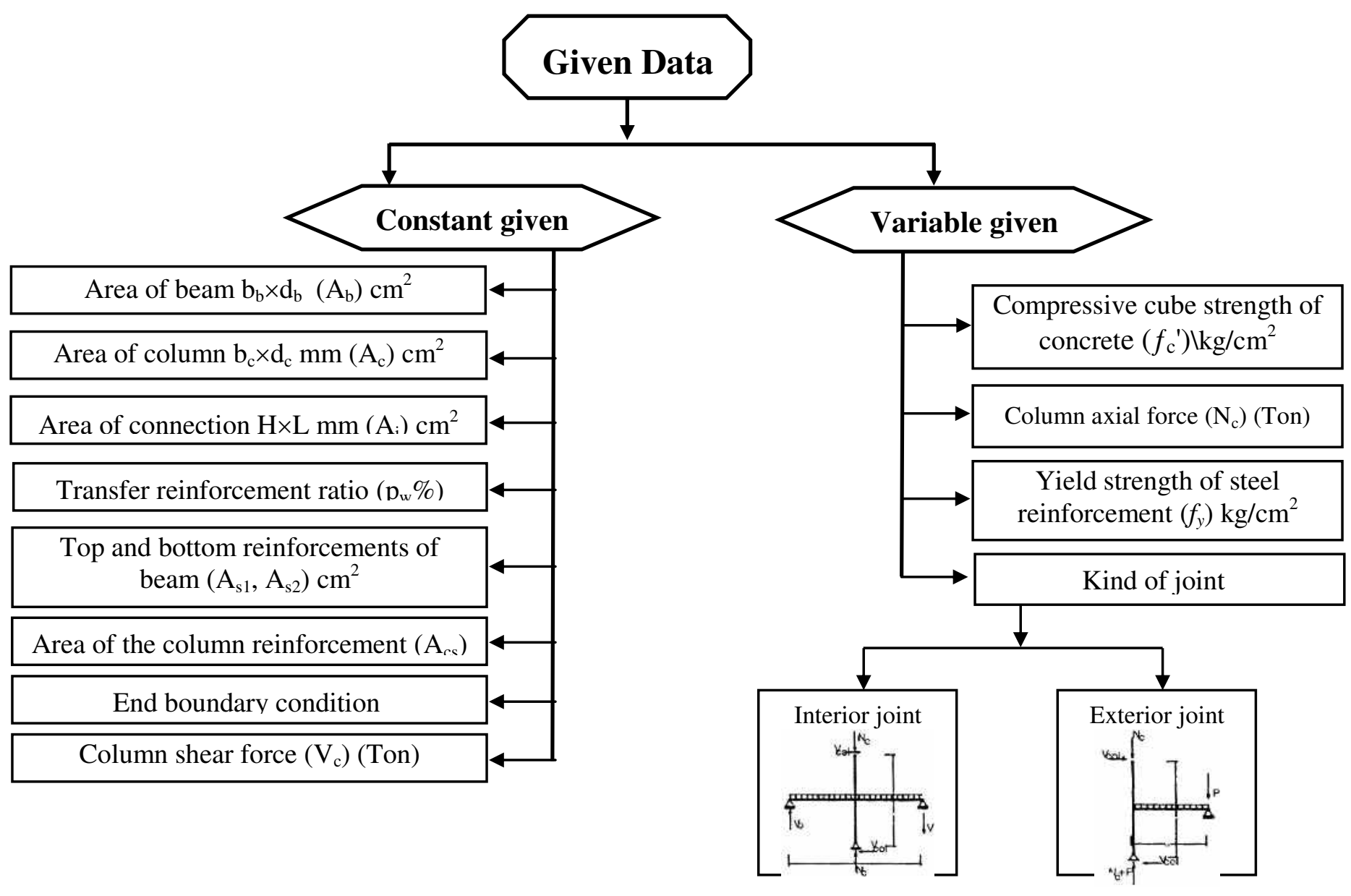


A. M. Ahmed et al, Static Behaviour of Different types of R.C Beam-Column Connections as Affected by Both Value of Acting Axial Normal Force and Grade of Used Concrete (Theoretical Study), pp. 321- 364

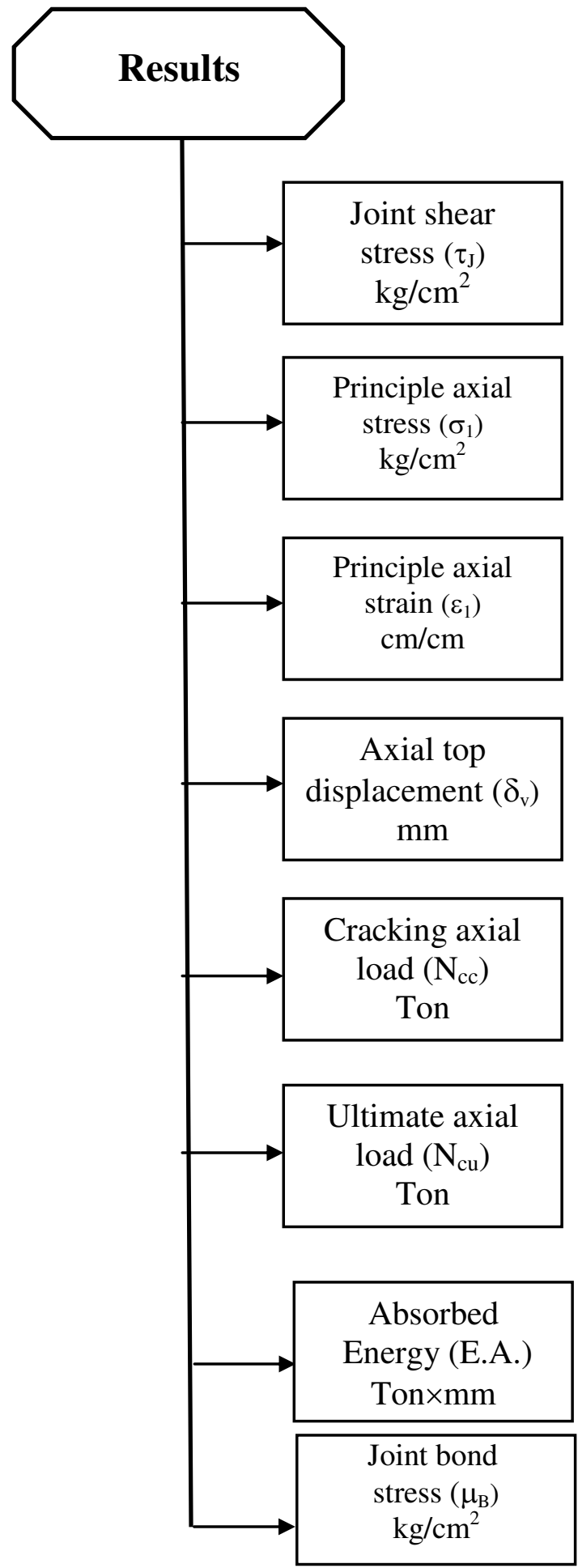

Journal of Engineering Sciences, Assiut University, Faculty of Engineering, Vol. 41, No. 2, March, 2013,E-mail address:jes@aun.edu.eg 
A. M. Ahmed et al, Static Behaviour of Different types of R.C Beam-Column Connections as Affected by Both Value of Acting Axial Normal Force and Grade of Used Concrete (Theoretical Study), pp. 321- 364

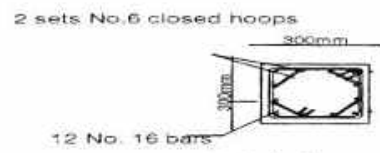

sec. 1-1

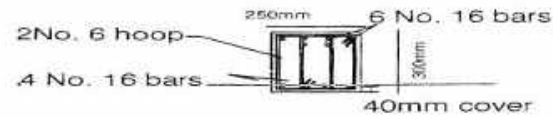

sec. $2-2$

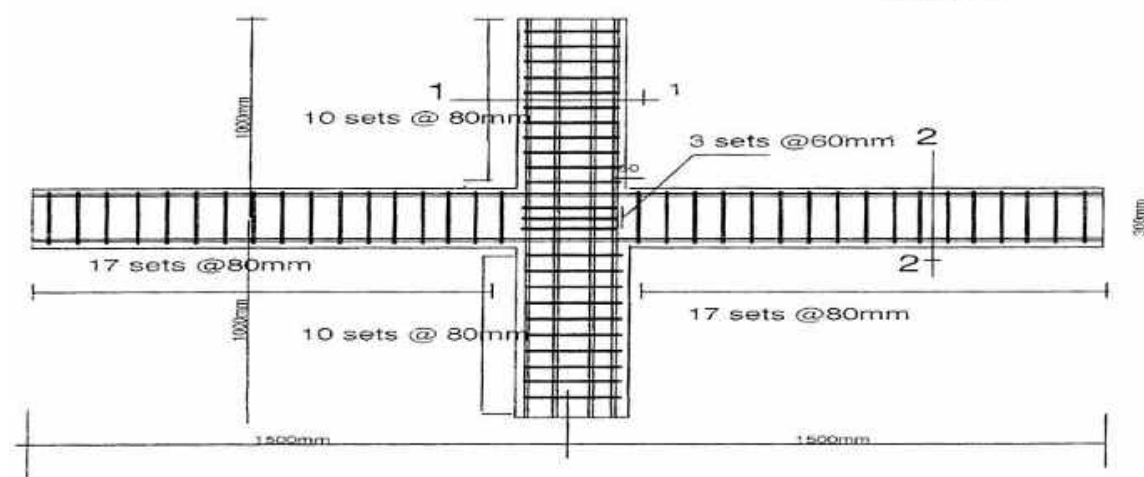

a) Reinforcement details of interior beam-column joint specimens

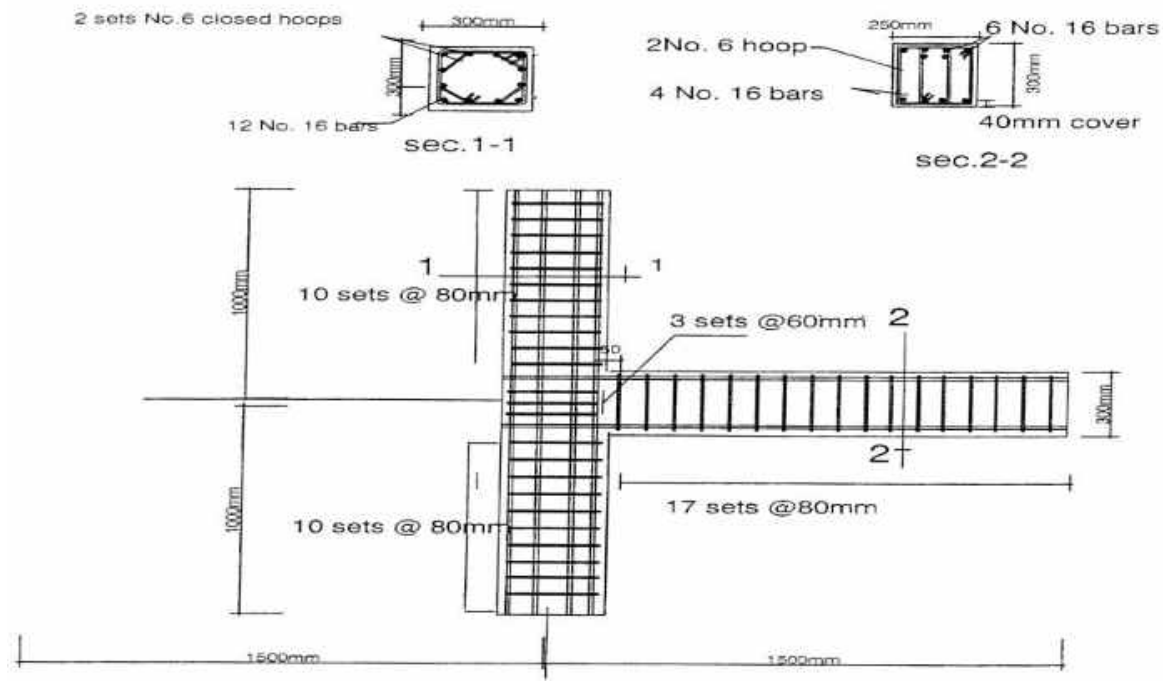

b) Reinforcement details of exterior beam-column joint specimens

Fig. 1. The reinforcement details of all the specimens

Journal of Engineering Sciences, Assiut University, Faculty of Engineering, Vol. 41, No. 2, March, 2013, E-mail address: jes@aun.edu.eg 
A. M. Ahmed et al, Static Behaviour of Different types of R.C Beam-Column Connections as Affected by Both Value of Acting Axial Normal Force and Grade of Used Concrete (Theoretical Study), pp. 321- 364

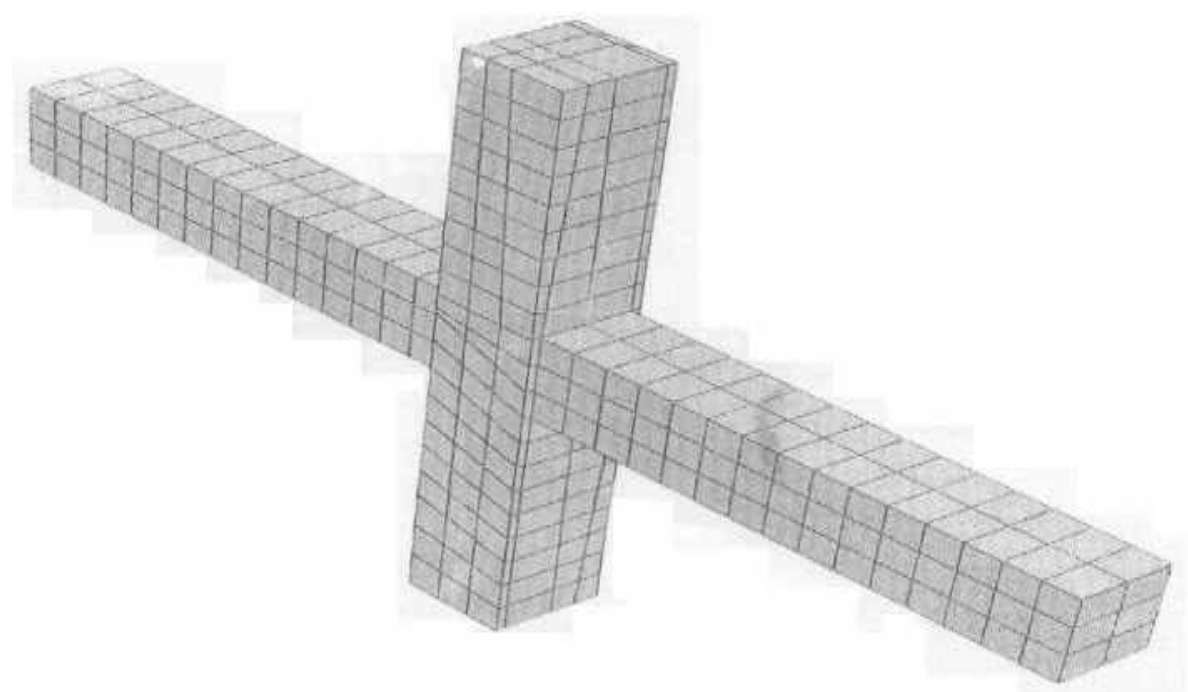

a) $3 \mathrm{D}$ view of meshed interior joint

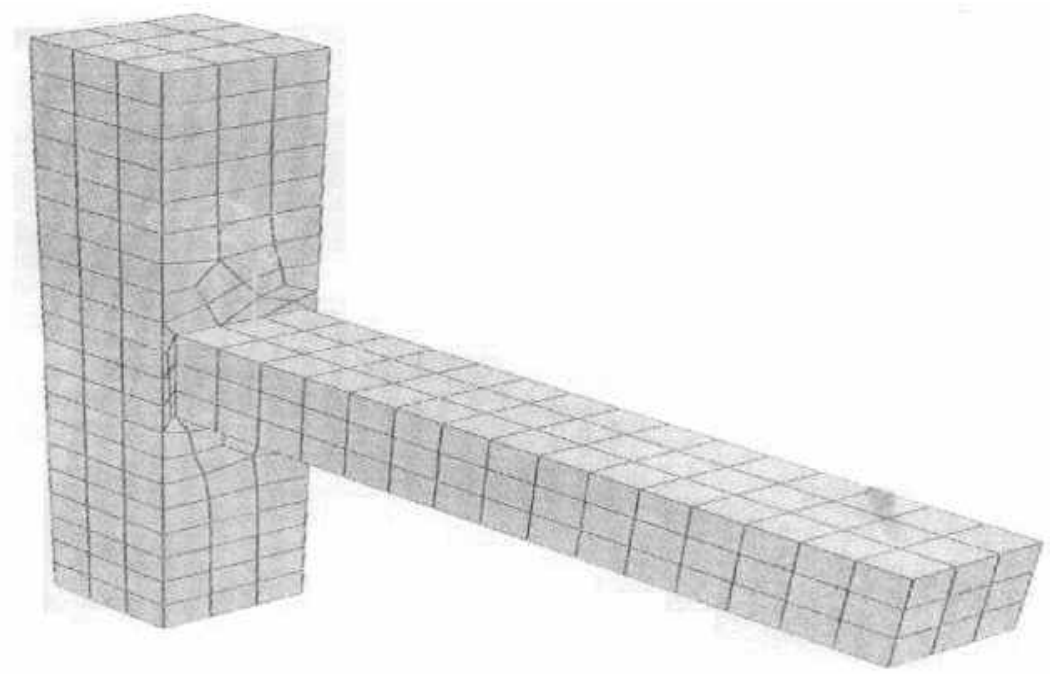

b) $3 \mathrm{D}$ view of meshed exterior joint

Fig. 2. $3 \mathrm{D}$ view of meshed joint

Journal of Engineering Sciences, Assiut University, Faculty of Engineering, Vol. 41, No. 2, March, 2013, E-mail address: jes@aun.edu.eg 
A. M. Ahmed et al, Static Behaviour of Different types of R.C Beam-Column Connections as Affected by Both Value of Acting Axial Normal Force and Grade of Used Concrete (Theoretical Study), pp. 321- 364

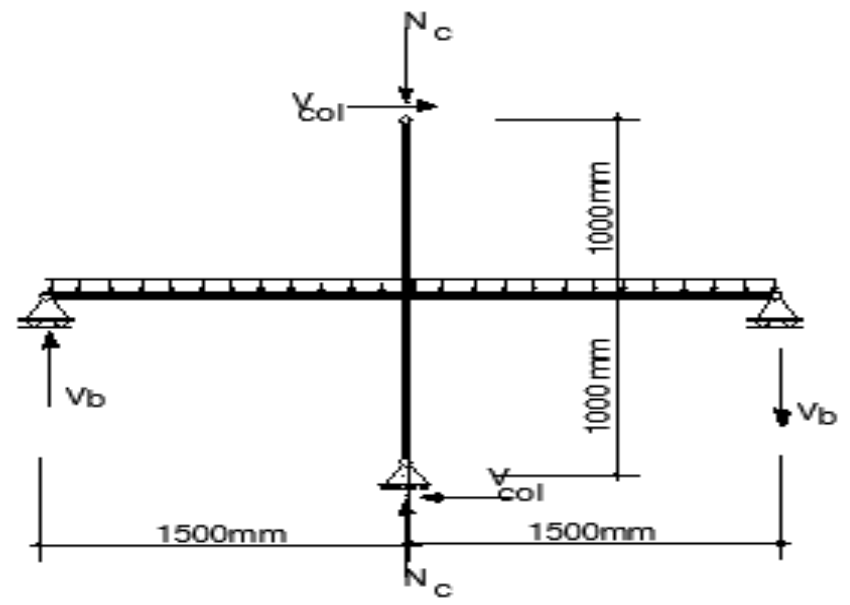

a) interior joint

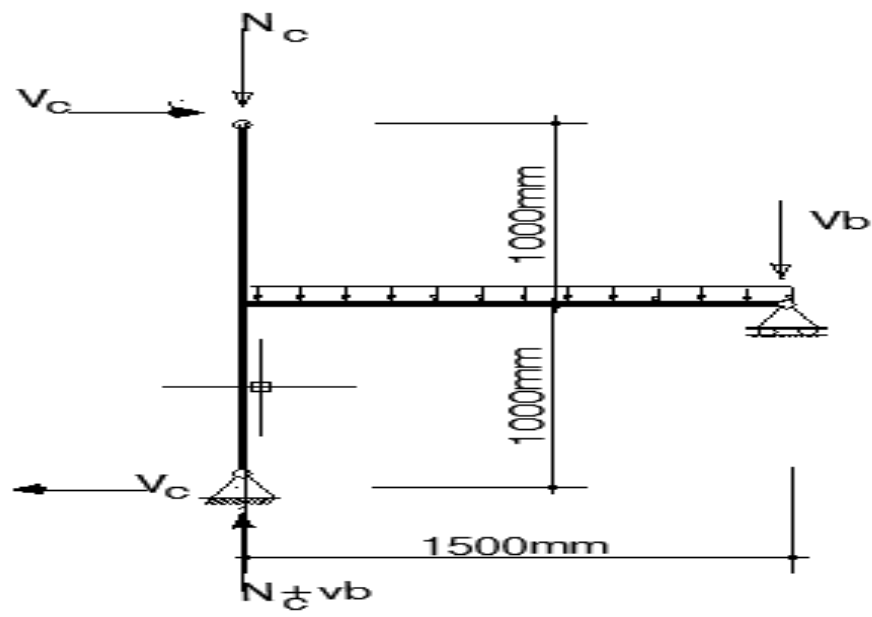

b) exterior joint

Fig. 3. The loading set up and Boundary condition of joints

The modifications were based on nonlinearity analytically model carried out by (Sam Lee 2008) The degradation factors for compression (dc) and tension (dt) are dependent on the plastic strain (ABAQUS, V6.5).

Journal of Engineering Sciences, Assiut University, Faculty of Engineering, Vol. 41, No. 2, March, 2013,E-mail address: jes@aun.edu.eg 
A. M. Ahmed et al, Static Behaviour of Different types of R.C Beam-Column Connections as Affected by Both Value of Acting Axial Normal Force and Grade of Used Concrete (Theoretical Study), pp. 321- 364

The nonlinearity of the structure includes geometry nonlinearity, material nonlinearity and a combination of both.

\section{Geometry nonlinearity:}

Geometry nonlinearity can be modeled accurately by use of the Green strain formula. The P- $\Delta$ effects and large deflection effects are automatically taken into account. Most general finite element analysis packages have this built-in function available.

\section{Material nonlinearity:}

Steel and concrete are the basic materials used in the structural elements. To model the cyclic characteristics of the earthquake load, a nonlinear material model with specific cyclic features should be used for each.

\section{$\underline{\text { Steel }}$}

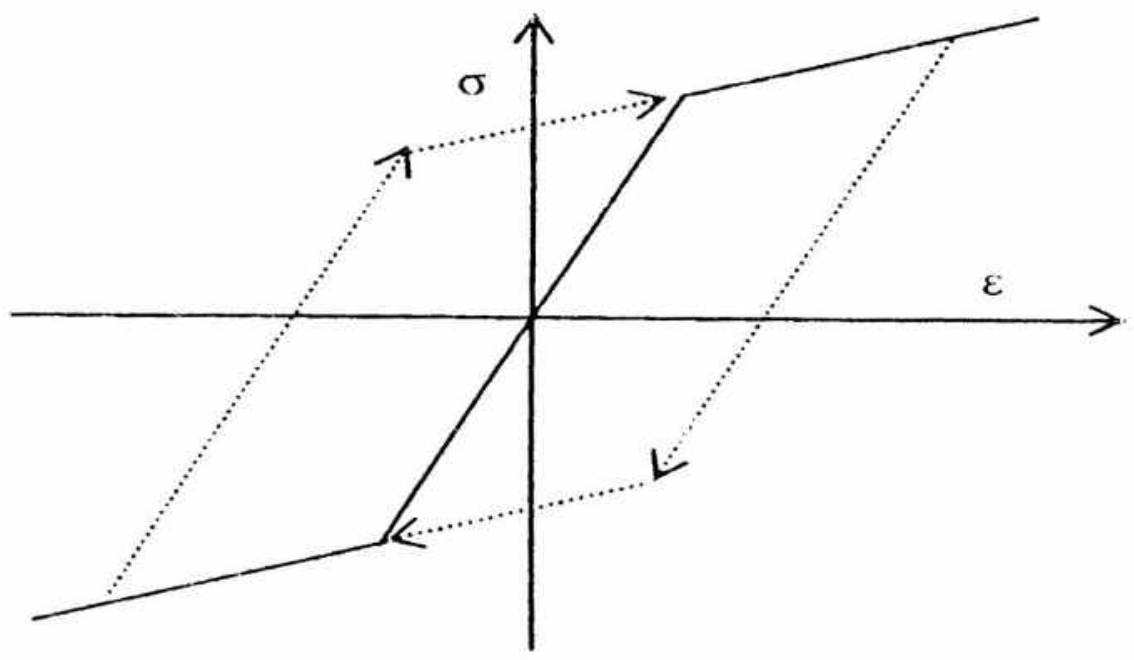

Fig. 4. Steel constitute law

In this article, an isotropic kinematics hardening model is used for steel material. As shown in Figure 4, the blushing effect has been taken into account, and there is no stiffness degradation during the cycling. It is acceptable for the skyscraper structure as the maximum steel strain should be less than $2.5 \%$.

\section{Concrete:}

The plastic-damage model (J. Lee, 1998) is used to model the concrete material. The model is a continuum, plasticity-based, damage model for concrete. It assumes that the main two failure mechanisms are tensile cracking and compressive crushing of the concrete material. It captures the three major characteristics of the concrete in the

buildings: (1) the strength of compression is larger than that of tension; (2) the stiffness degrades when it goes into plastic range; (3) the stiffness recovers when it reverses from tension to compression. 
A. M. Ahmed et al, Static Behaviour of Different types of R.C Beam-Column Connections as Affected by Both Value of Acting Axial Normal Force and Grade of Used Concrete (Theoretical Study), pp. 321- 364

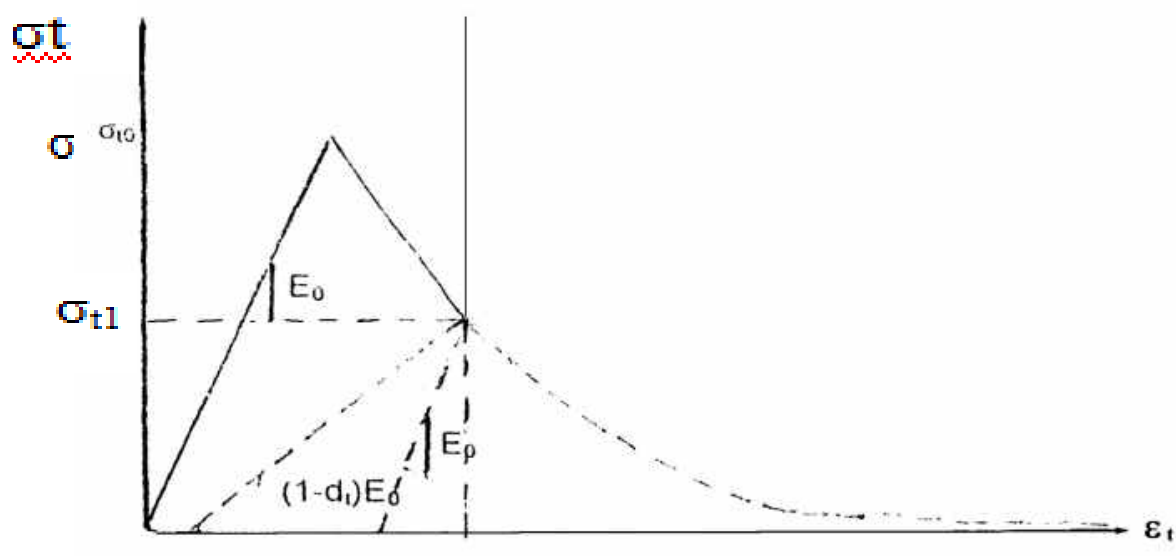

Fig. 5. Concrete in tension (Sam Lee 2008)

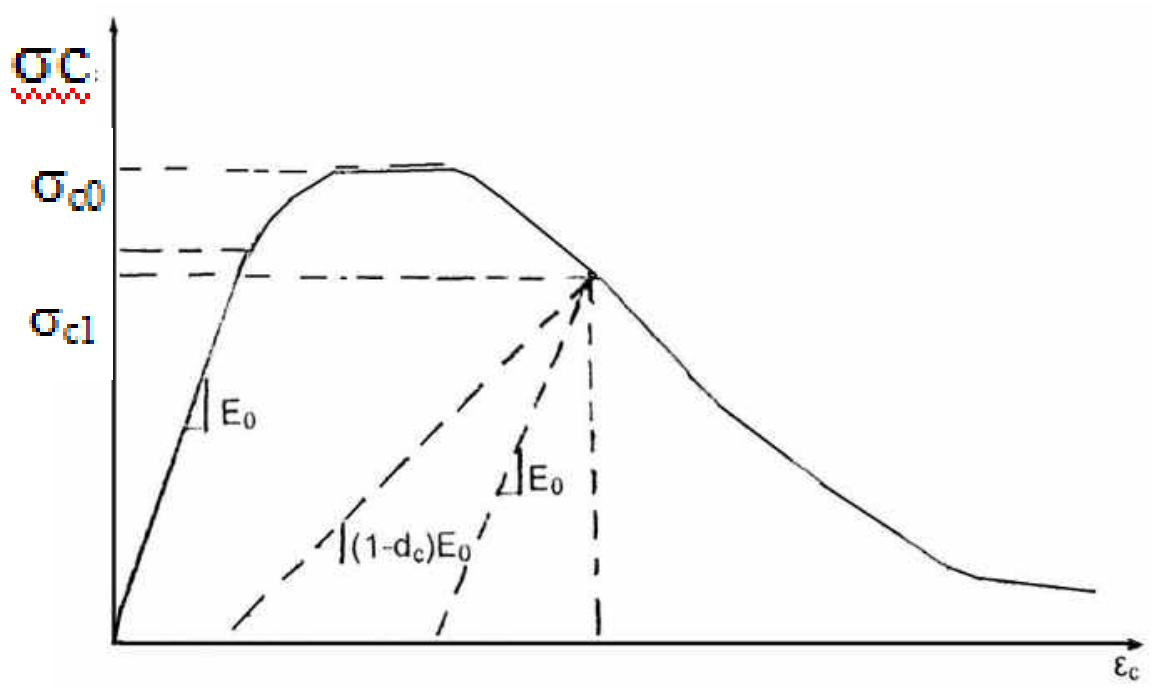

Fig. 6. Concrete in compression (Sam Lee 2008)

Figure 5 and Figure 6 show the concrete material's stress-strain curve, the stiffness of the concrete degrades when it unloads from the plastic range. The degradation factors for compression (dc) and tension (dt) are dependent on the plastic strain (ABAQUS, V6.5). Figure 7 shows the hysteric curve of the concrete, it can be seen that the stiffness recovers when the material stress status reverses from tension to compression. 


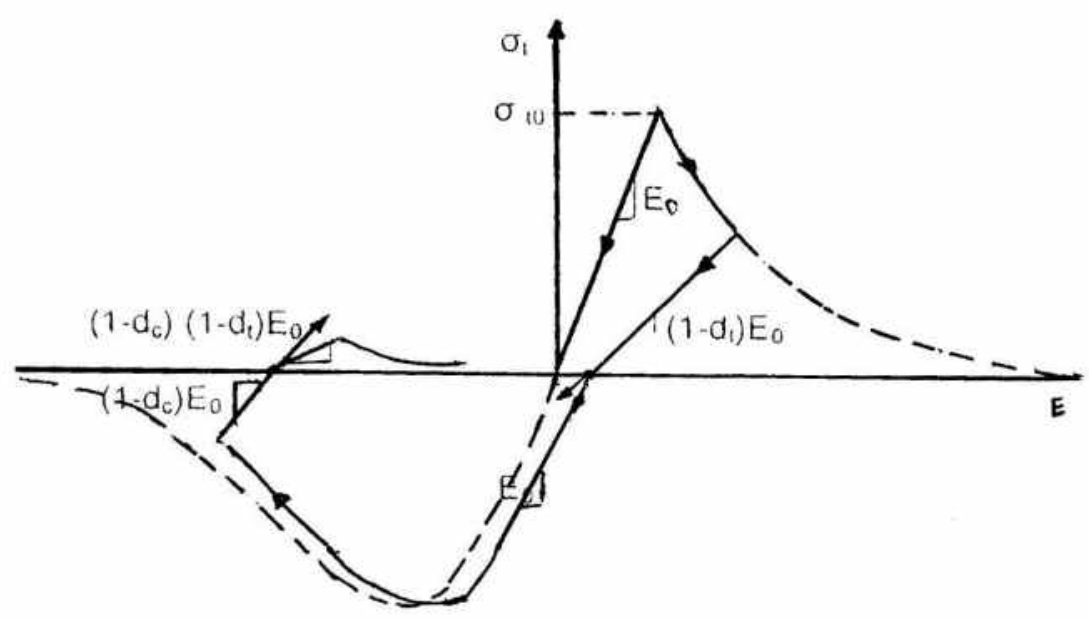

Fig. 7. Concrete hysteric curve (Sam Lee 2008)

In the fixed crack model, the crack direction is determined and fixed at the time of crack initiation. In the rotating crack model .The crack direction is identical with a principal strain direction and rotates if the strain direction changes. The main difference in these crack models is the absence of shear stresses on the crack plane in the rotating crack model due coincidence of principal strain directions with the crack orientation, which makes the rotating crack model more simple. In the fixed crack model the shear resistance of the cracks is modeled by means of the variable shear retention factor, which reflects the aggregate interlock effect of cracked concrete. Concrete in plane stress condition can be well described by a damage model such as the one used in the ABAQUS, see Fig. 8. It is based on the "equivalent uniaxial law", which covers the complete range of the plane stress behaviour in tension and compression. The effect of biaxial stress state on the concrete strength is captured by the failure function due to (Kupfer et al., 2011). For the tensile response (cracking) the crack band method described above is applied. Similar method is applied for the compressive softening. Thus complete softening behaviour is based on an objective and mesh independe1nt approach.

\section{Data given and obtained results}

The loading set up, specimens statically cyclic lateral load was applied maintaining variable axial load at the top of the column for interior and exterior joint only so as knee joint has no axial load were supported in vertical position. To investigate the influence of concrete compressive strength on the seismic behavior of interior, exterior beam column joints under different axial loading levels were analyzed by the FEM software ABAQUSICAE and corresponding story shear force versus horizontal displacement. 
A. M. Ahmed et al, Static Behaviour of Different types of R.C Beam-Column Connections as Affected by Both Value of Acting Axial Normal Force and Grade of Used Concrete (Theoretical Study), pp. 321- 364

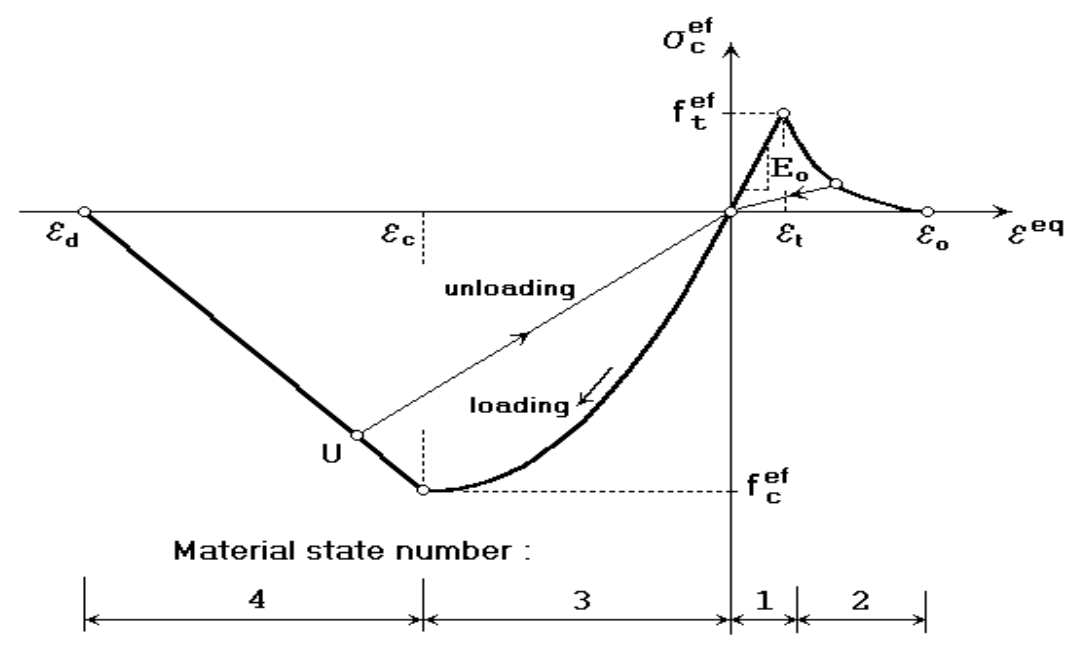

Fig. 8. Equivalent uniaxial law

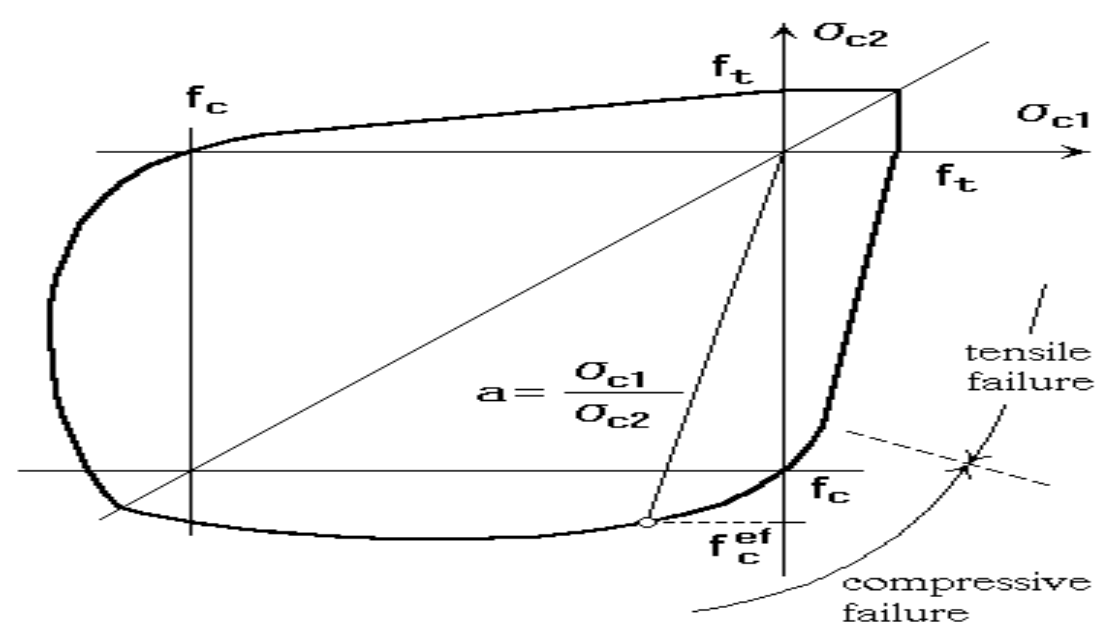

Bi-axial failure function by Kupfer 2011

With different applied axial loads at which ultimate and cracking axial load was accrued, the maximum joint shear stresses observed, absorbed energy, failure mode several linear variable displacement transducers were mounted on the test specimens to measure the net story drift, joint rotation, gap openings, and shear deformations, the net column top displacement $(\Delta h)$ was calculated by subtracting the column base lateral displacement from the lateral displacement measurement at the column top.

Figure 9 shows modeling connections with loading and boundary condition and deflection shapes studying by ABAQUSICAE 6.7 software for interior, exterior joints. The 
A. M. Ahmed et al, Static Behaviour of Different types of R.C Beam-Column Connections as Affected by Both Value of Acting Axial Normal Force and Grade of Used Concrete (Theoretical Study), pp. 321- 364

studied joints are listed in Tables 2 and 3 they are 32 interior and exterior beam-to-column joint sub assemblages.
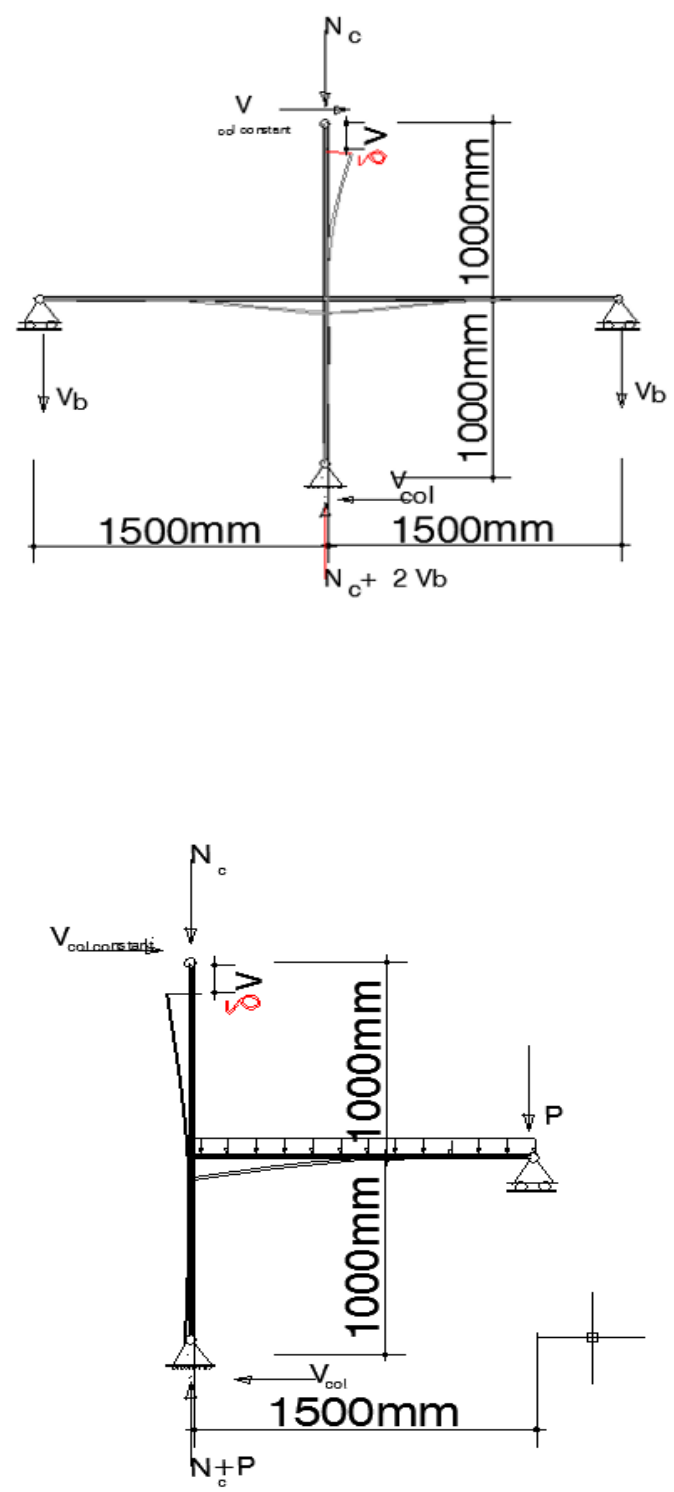

Fig. 9. Loads and deflection shapes at definition boundary condition

The obtained theoretically evaluated values of various stresses and displacements for both interior and exterior joints for the case study are tabulated and given in Tables (2) and (3).

Journal of Engineering Sciences, Assiut University, Faculty of Engineering, Vol. 41, No. 2, March, 2013, E-mail address: jes@aun.edu.eg 
A. M. Ahmed et al, Static Behaviour of Different types of R.C Beam-Column Connections as Affected by Both Value of Acting Axial Normal Force and Grade of Used Concrete (Theoretical Study), pp. 321- 364

\section{Table 2}

Obtained theoretical results for studied interior beam-column joints.

\begin{tabular}{|c|c|c|c|c|c|c|c|c|c|c|}
\hline Joint No. & $\begin{array}{c}\text { Compressive } \\
\text { concrete } \\
\left(f_{c}\right)\left(\mathrm{kg} / \mathrm{cm}^{2}\right)\end{array}$ & $\begin{array}{c}\text { Yield } \\
\text { strength } \\
\left(f_{y}\right) \\
\left(\mathbf{k g} / \mathrm{cm}^{2}\right)\end{array}$ & $\begin{array}{c}\text { Lateral } \\
\text { load (ton) } \\
\left(V_{c}\right)\end{array}$ & $\begin{array}{c}\text { Axial } \\
\text { load (ton) } \\
\left(\mathbf{N}_{\mathbf{c}}\right)\end{array}$ & $\begin{array}{c}\mathbf{N}_{\mathrm{c}} / \\
\left(f_{\mathrm{c}}\right) \mathbf{A}_{\mathrm{c}}\end{array}$ & $\begin{array}{c}\text { Top Axial } \\
\text { Displacement } \\
\text { mm }(\delta v)\end{array}$ & $\begin{array}{c}\text { Max. } \\
\text { principle } \\
\text { stress } \\
\left(\mathbf{k g} / \mathbf{c m}^{2}\right)\left(\sigma_{1}\right)\end{array}$ & $\begin{array}{l}\text { Joint shear } \\
\text { stress } \\
\left(\mathbf{k g} / \mathrm{cm}^{2}\right)\left(\tau_{\mathrm{J}}\right)\end{array}$ & $\begin{array}{c}\text { Max. } \\
\text { principle } \\
\text { strain } \\
\text { cm/cm } \\
\left(\varepsilon_{1} \times 10^{-4}\right)\end{array}$ & $\begin{array}{c}\text { Energy } \\
\text { Absorption } \\
\text { E.A } \\
(\text { Ton } \times \mathbf{m m})\end{array}$ \\
\hline $\mathrm{J}(1)$ & 250 & 2400 & 0 & 0 & 0 & 0 & 0 & 62.23 & 0 & 0 \\
\hline $\mathrm{J}(2)$ & 250 & 2400 & 50 & 65 & 0.28 & 12 & 97.60 & 80.04 & 2.36 & 1382 \\
\hline $\mathrm{J}(3)$ & 250 & 2400 & 50 & 115 & 0.52 & 20.23 & 96.38 & 79.44 & 2.33 & 2300 \\
\hline $\mathrm{J}(4)$ & 250 & 2400 & 50 & 131 & 0.58 & 24.50 & 95.16 & 78.55 & 2.85 & 2764 \\
\hline $\mathrm{J}(5)$ & 400 & 2800 & 0 & 0 & 0 & 0 & 0 & 80.4 & 0 & 0 \\
\hline $\mathrm{J}(6)$ & 400 & 2800 & 50 & 100 & 0.27 & 20.80 & 123.75 & 99.31 & 3.05 & 2150 \\
\hline $\mathrm{J}(7)$ & 400 & 2800 & 50 & 177 & 0.49 & 34.50 & 122 & 98.86 & 2.96 & 3978 \\
\hline $\mathrm{J}(8)$ & 400 & 2800 & 50 & 187 & 0.52 & 40.22 & 120 & 96.50 & 3.66 & 4730 \\
\hline $\mathrm{J}(9)$ & 600 & 3600 & 0 & 0 & 0 & 0 & 0 & 100.55 & 0 & 0 \\
\hline $\mathrm{J}(10)$ & 600 & 3600 & 50 & 120 & 0.22 & 25.20 & 168 & 129.12 & 4.10 & 2886 \\
\hline $\mathrm{J}(11)$ & 600 & 3600 & 50 & 218 & 0.41 & 37.20 & 166 & 128.76 & 4.05 & 3930 \\
\hline $\mathrm{J}(12)$ & 600 & 3600 & 50 & 254 & 0.47 & 44.08 & 164 & 128.30 & 4.70 & 5080 \\
\hline $\mathrm{J}(13)$ & 1200 & 4000 & 0 & 0 & 0 & 0 & 0 & 142.90 & 0 & 0 \\
\hline $\mathrm{J}(14)$ & 1200 & 4000 & 50 & 200 & 0.18 & 40.00 & 218 & 162 & 5.87 & 6000 \\
\hline $\mathrm{J}(15)$ & 1200 & 4000 & 50 & 398 & 0.36 & 58.20 & 215 & 161.63 & 5.70 & 8701 \\
\hline $\mathrm{J}(16)$ & 1200 & 4000 & 50 & 452 & 0.42 & 65 & 211 & 161.42 & 6.10 & 9752 \\
\hline
\end{tabular}


A. M. Ahmed et al, Static Behaviour of Different types of R.C Beam-Column Connections as Affected by Both Value of Acting Axial Normal Force and Grade of Used Concrete (Theoretical Study), pp. 321- 364

\section{Table 3}

Obtained theoretical results for studied exterior beam-cColumn joints.

\begin{tabular}{|c|c|c|c|c|c|c|c|c|c|c|}
\hline Joint No. & $\begin{array}{c}\text { Compressive } \\
\text { concrete } \\
\left(f_{c}\right)\left(\mathrm{kg} / \mathrm{cm}^{2}\right)\end{array}$ & $\begin{array}{c}\text { Yield } \\
\text { strength } \\
\left(f_{y}\right) \\
\left(\mathbf{k g} / \mathrm{cm}^{2}\right)\end{array}$ & $\begin{array}{c}\text { Lateral } \\
\text { load (ton) } \\
\left(V_{c}\right)\end{array}$ & $\begin{array}{c}\text { Axial load } \\
(\text { ton })\left(\mathbf{N}_{c}\right)\end{array}$ & $\begin{array}{c}\mathbf{N}_{c} / \\
\left(f_{c}\right) \mathbf{A}_{c}\end{array}$ & $\begin{array}{c}\text { Top Axial } \\
\text { Displacement } \\
\text { mm }(\delta \mathbf{v})\end{array}$ & $\begin{array}{c}\text { Max. principle } \\
\text { stress } \\
\left(\mathbf{k g} / \mathrm{cm}^{2}\right)\left(\sigma_{1}\right)\end{array}$ & $\begin{array}{c}\text { Joint shear } \\
\text { stress } \\
\left(\mathrm{kg} / \mathrm{cm}^{2}\right)\left(\tau_{\mathrm{J}}\right)\end{array}$ & $\begin{array}{c}\text { Max. } \\
\text { principle } \\
\text { strain } \\
\text { cm/cm } \\
\left(\varepsilon_{1} \times 10^{-4}\right) \\
\end{array}$ & $\begin{array}{c}\text { Energy } \\
\text { Absorption E.A } \\
(\text { Ton } \times \text { mm })\end{array}$ \\
\hline $\mathrm{J}(17)$ & 250 & 2400 & 0 & 0 & 0 & 0 & 0 & 45.40 & 0 & 0 \\
\hline $\mathrm{J}(18)$ & 250 & 2400 & 50 & 35 & 0.16 & 5.20 & 75.4 & 58.06 & 1.08 & 310 \\
\hline J (19) & 250 & 2400 & 50 & 70 & 0.20 & 10.75 & 71.20 & 57.14 & 1.03 & 665 \\
\hline $\mathbf{J}(20)$ & 250 & 2400 & 50 & 120 & 0.53 & 18.80 & 67.95 & 56.63 & 1.55 & 1179 \\
\hline $\mathbf{J}(21)$ & 400 & 2800 & 0 & 0 & 0 & 0 & 0 & 60.80 & 0 & 0 \\
\hline $\mathrm{J}(22)$ & 400 & 2800 & 50 & 30 & 0.10 & 7.870 & 92.49 & 74.20 & 1.86 & 627 \\
\hline $\mathbf{J}(23)$ & 400 & 2800 & 50 & 95 & 0.26 & 20.48 & 90.87 & 73.50 & 1.80 & 1567 \\
\hline $\mathrm{J}(24)$ & 400 & 2800 & 50 & 152 & 0.42 & 32.63 & 89.05 & 72.42 & 2.06 & 2508 \\
\hline $\mathrm{J}(25)$ & 600 & 3600 & 0 & 0 & 0 & 0 & 0 & 80.08 & 0 & 0 \\
\hline $\mathrm{J}(26)$ & 600 & 3600 & 50 & 50 & 0.10 & 10.43 & 128.7 & 99.54 & 3.79 & 930 \\
\hline $\mathrm{J}(27)$ & 600 & 3600 & 50 & 129 & 0.23 & 24.35 & 126.7 & 98.14 & 2.85 & 2232 \\
\hline $\mathrm{J}(28)$ & 600 & 3600 & 50 & 186 & 0.34 & 36.25 & 124.12 & 96.27 & 4.20 & 3348 \\
\hline J (29) & 1200 & 4000 & 0 & 0 & 0 & 0 & 0 & 110.77 & 0 & 0 \\
\hline $\mathbf{J}(30)$ & 1200 & 4000 & 50 & 100 & 0.10 & 18.82 & 178.6 & 132.84 & 4.36 & 2200 \\
\hline $\mathrm{J}(31)$ & 1200 & 4000 & 50 & 181 & 0.17 & 31.07 & 176 & 130.1 & 4.18 & 3790 \\
\hline $\mathbf{J}(32)$ & 1200 & 4000 & 50 & 320 & 0.29 & 53.50 & 173 & 128.25 & 5.805 & 6480 \\
\hline
\end{tabular}


A. M. Ahmed et al, Static Behaviour of Different types of R.C Beam-Column Connections as Affected by Both Value of Acting Axial Normal Force and Grade of Used Concrete (Theoretical Study), pp. 321- 364

The effects of the most of parameters, which may influence the behavior of beam-column joint are evaluated and can be represented by the following relationships:

\section{Relation of axial column loads $\left(\mathbf{N}_{\mathrm{c}}\right)$ versus axial displacement $(\delta \mathrm{v})$.}

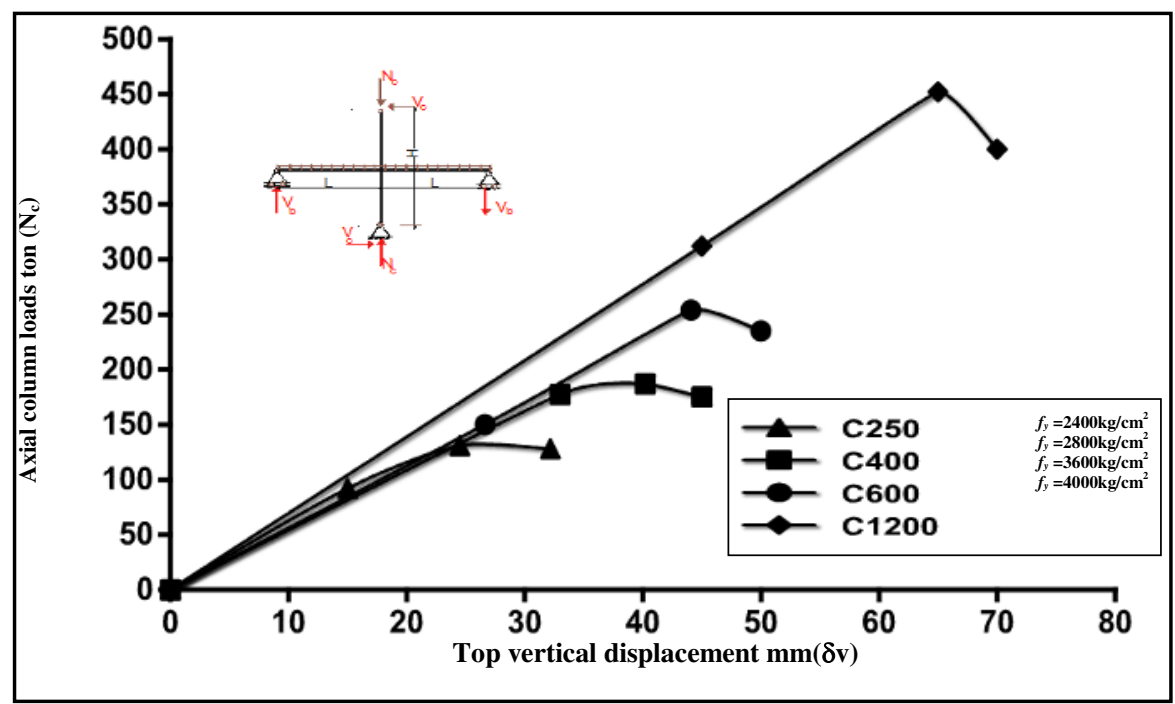

a) Relation of Axial column loads $\left(\mathrm{N}_{\mathrm{c}}\right)-$ Axial displacement $\left(\delta_{\mathrm{v}}\right)$ at Interior joint

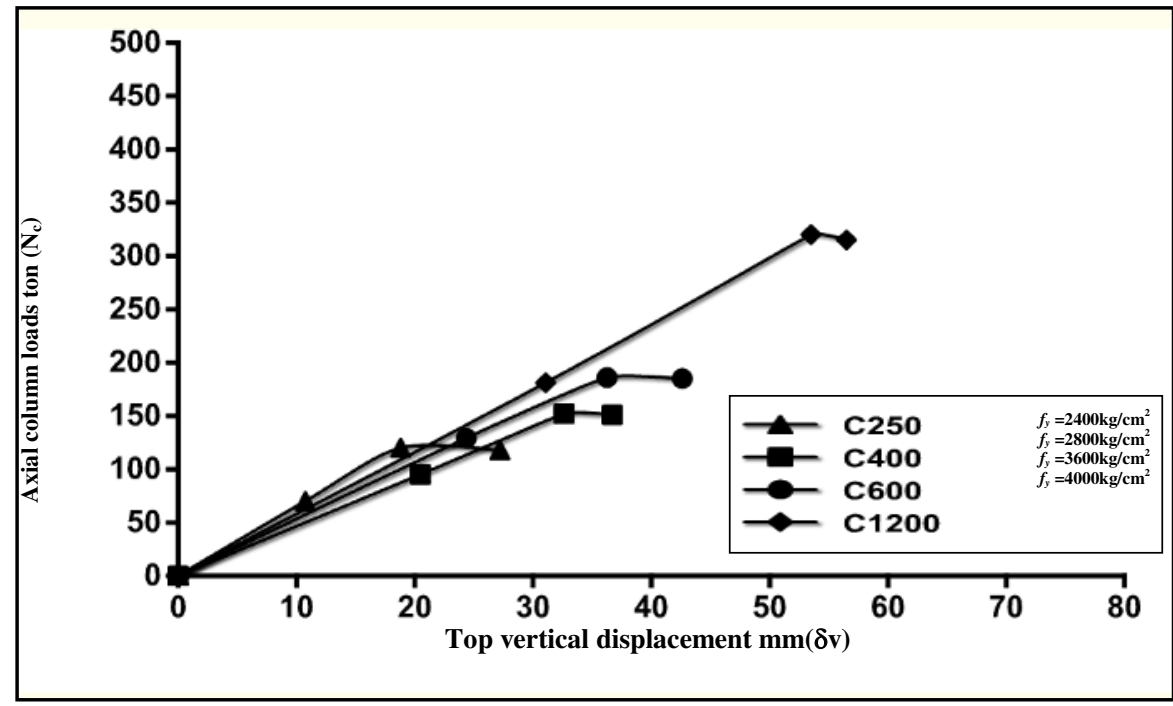

b) Relation of axial column loads $\left(\mathrm{N}_{\mathrm{c}}\right)$ - axial displacement $\left(\delta_{\mathrm{v}}\right)$ at exterior joint

Fig. 10. Relation of axial column loads $\left(\mathrm{N}_{\mathrm{c}}\right)$ - axial displacement $\left(\delta_{\mathrm{v}}\right)$

Fig.10 illustrates that in general as the axial load $\left(\mathrm{N}_{\mathrm{c}}\right)$ increases the corresponding axial top vertical displacement $\left(\delta_{\mathrm{v}}\right)$ increases.

Journal of Engineering Sciences, Assiut University, Faculty of Engineering, Vol. 41, No. 2, March, 2013,E-mail address: jes@aun.edu.eg 
A. M. Ahmed et al, Static Behaviour of Different types of R.C Beam-Column Connections as Affected by Both Value of Acting Axial Normal Force and Grade of Used Concrete (Theoretical Study), pp. 321- 364

\section{Relation of shear stress $\left(\tau_{\mathrm{J}}\right)$ versus axial load ratio $\left(\mathbf{N}_{\mathrm{c}} \backslash \mathbf{A}_{\mathrm{c}} \boldsymbol{f}_{\mathrm{c}}{ }_{\mathrm{c}} \%\right)$.}

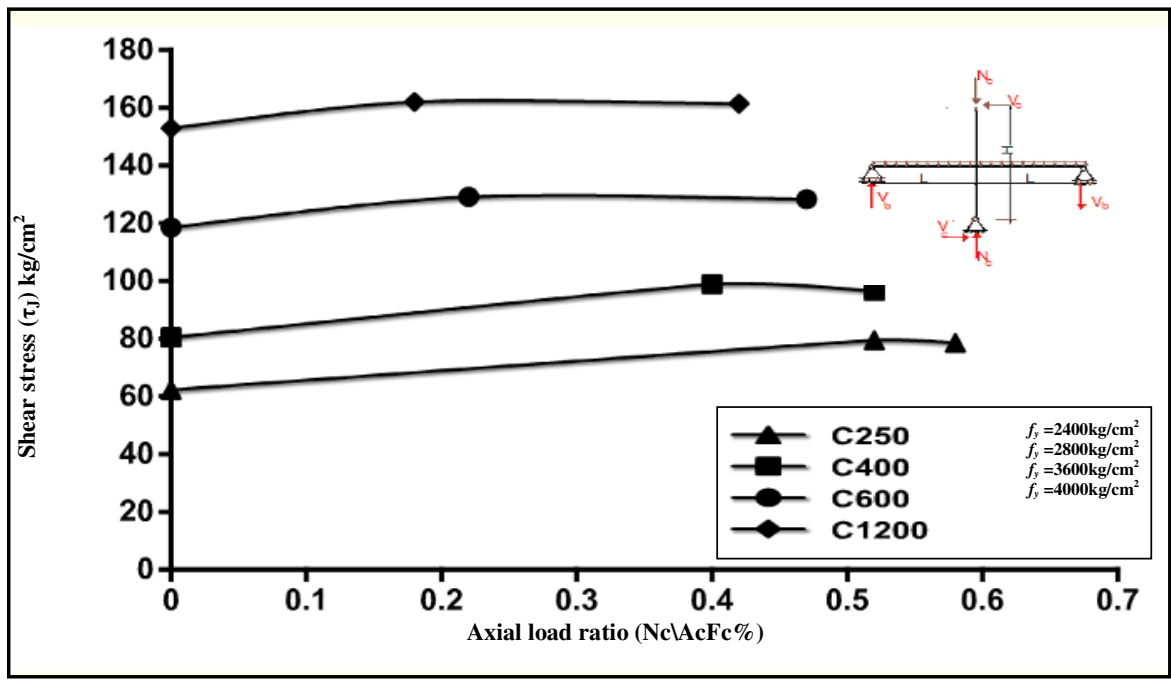

a) Relation of shear stress $\left(\tau_{\mathbf{J}}\right)$ - axial column loads ratio $\left(\mathrm{N}_{\mathbf{c}} \backslash \mathrm{F}_{\mathbf{c}} \mathrm{A}_{\mathbf{c}} \%\right)$ at interior joint

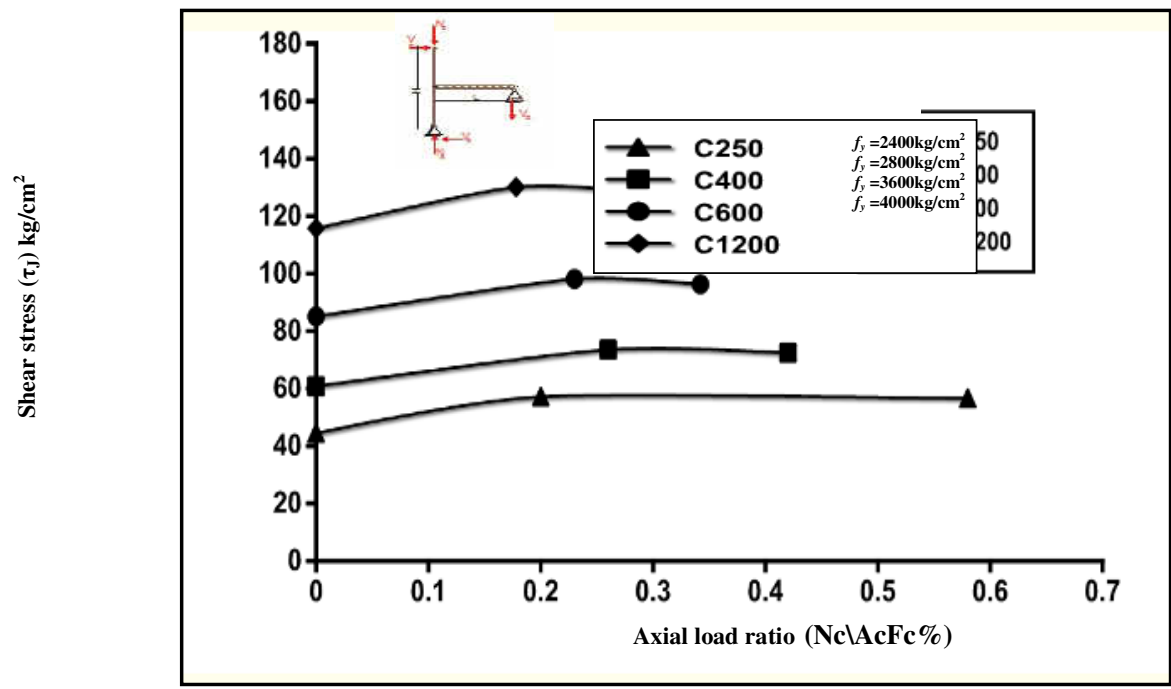

b) Relation of Shear Stress $\left(\tau_{\mathbf{J}}\right)-$ Axial column loads ratio $\left(\mathrm{N}_{\mathbf{c}} \mid \mathrm{F}_{\mathbf{c}} \mathrm{Ac} \%\right)$ at Exterior joint

Fig. 11. Relation of shear stress $\left(\tau_{\mathrm{J}}\right)$ and axial column loads ratio ( $\left.\mathrm{Nc} \backslash \mathrm{FcAc} \%\right)$

Fig. 11 shows that the joint shear stress $\left(\tau_{\mathrm{J}}\right)$ increases with increasing the axial load ratio $\left(\mathrm{N}_{\mathrm{c}} \backslash \mathrm{A}_{\mathrm{c}} \mathrm{Fc} \%\right)$, for both studied joints.

Journal of Engineering Sciences, Assiut University, Faculty of Engineering, Vol. 41, No. 2, March, 2013,E-mail address:jes@aun.edu.eg 
A. M. Ahmed et al, Static Behaviour of Different types of R.C Beam-Column Connections as Affected by Both Value of Acting Axial Normal Force and Grade of Used Concrete (Theoretical Study), pp. 321- 364

\section{Relation of shear stress $\left(\tau_{\mathrm{J}}\right) \mathrm{kg} / \mathrm{cm}^{2}$-principle axial Stress $\left(\sigma_{1}\right) \mathrm{kg} / \mathrm{cm}^{2}$ Fig. (12)}

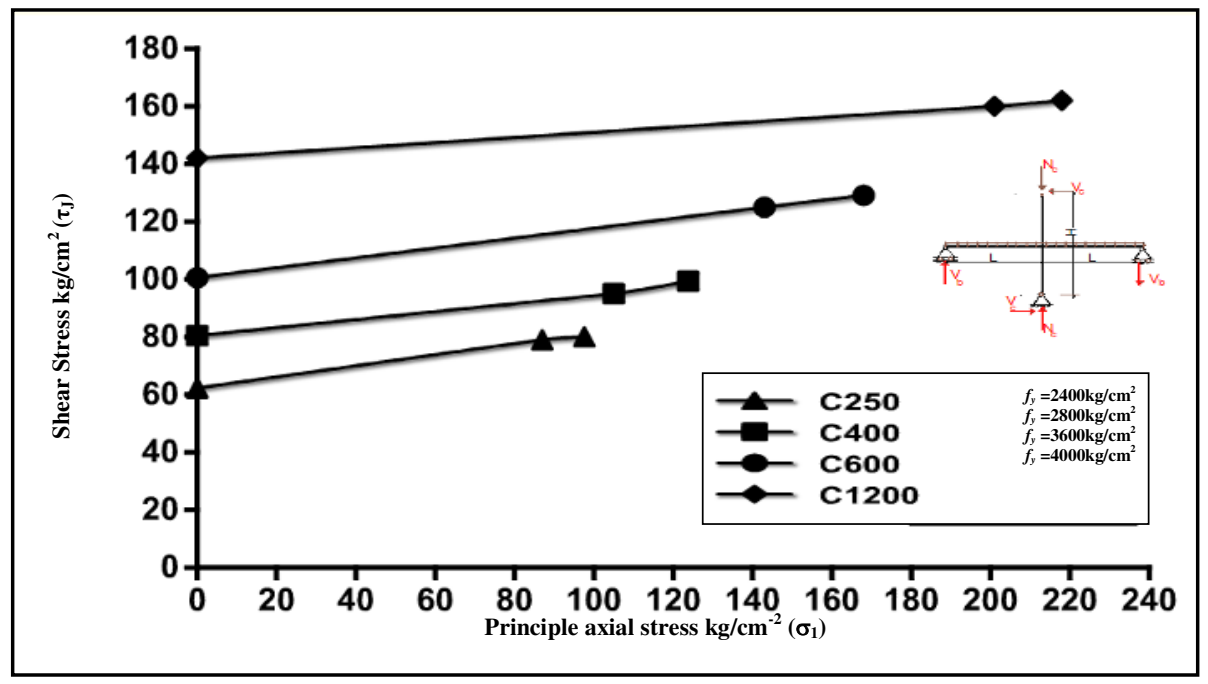

a) Relation of shear Stress $\left(\tau_{\mathrm{J}}\right)$-a principle axial stress $\left(\sigma_{1}\right) \mathrm{kg} / \mathrm{cm}^{2}$ for Interior Joint

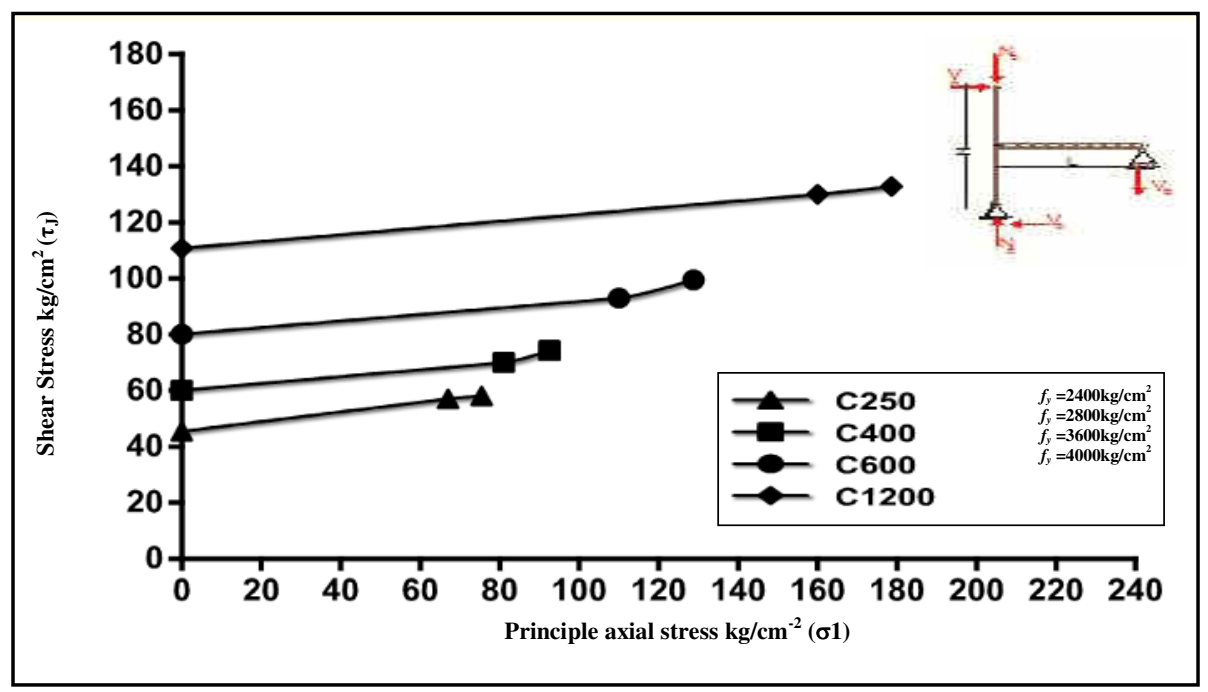

b) Relation of shear Stress $\left(\tau_{\mathrm{J}}\right)$-a Principle axial stress $\left(\sigma_{1}\right) \mathrm{kg} / \mathrm{cm}^{2}$ at exterior joint

Fig. 12. Relation of shear stress $\left(\tau_{\mathrm{J}}\right)$ and a principle axial stress $\left(\sigma_{1}\right)$

Fig.12 illustrates that in general as the axial stress $\left(\sigma_{1}\right)$ increases the corresponding shear stress $\left(\tau_{\mathrm{J}}\right)$ also increases approximately in linear relationship of constant rate disregarding the grade of concrete.

Journal of Engineering Sciences, Assiut University, Faculty of Engineering, Vol. 41, No. 2, March, 2013,E-mail address: jes@aun.edu.eg 
A. M. Ahmed et al, Static Behaviour of Different types of R.C Beam-Column Connections as Affected by Both Value of Acting Axial Normal Force and Grade of Used Concrete (Theoretical Study), pp. 321- 364

\section{Relation of energy absorption (E.A)-vertical top displacement $\left(\delta_{v}\right)$}

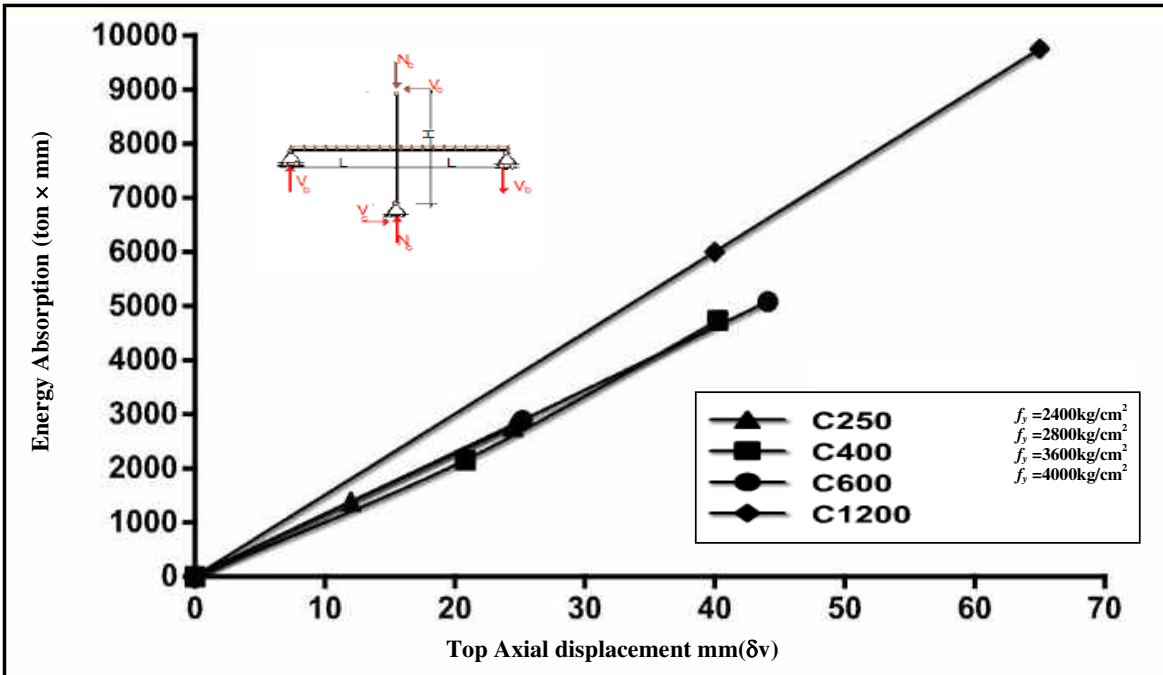

a) Relation of energy absorption (E.A)-vertical top displacement $\left(\delta_{v}\right)$ for interior joint

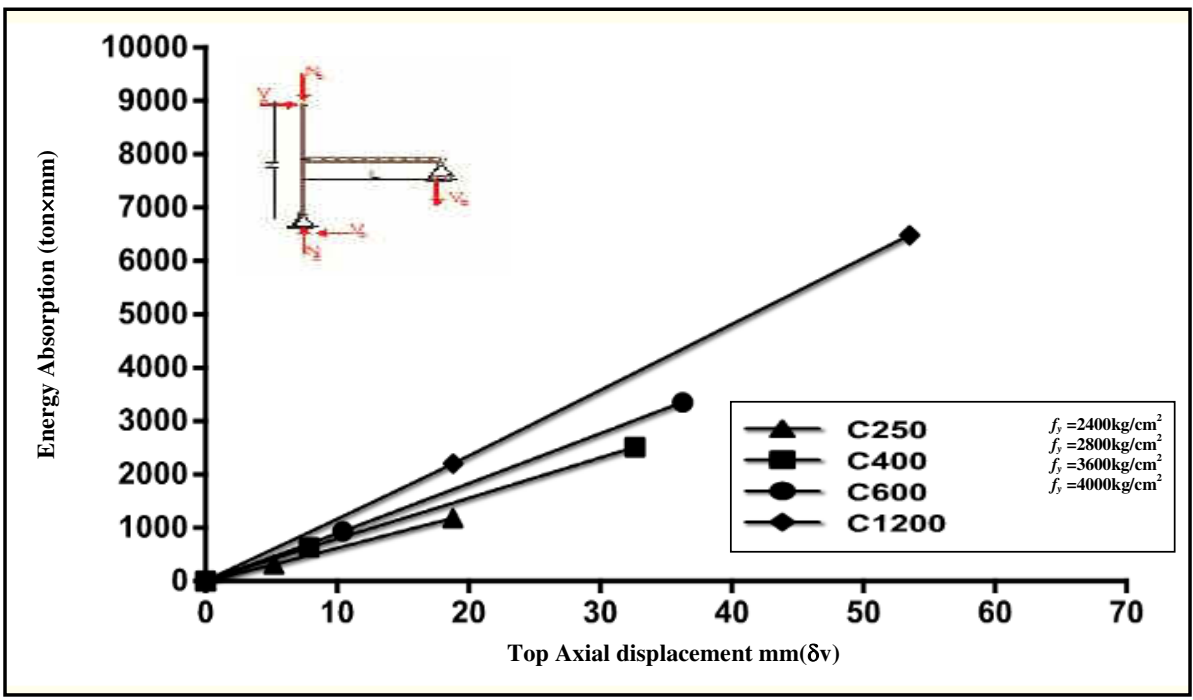

b) Relation of energy absorption (E.A)-vertical top displacement $\left(\delta_{v}\right)$ at exterior joint

Fig. 13. Relation of energy absorption (E.A) versus vertical top displacement $\left(\delta_{\mathrm{v}}\right)$

Fig.13 illustrates that in general as vertical top displacement $\left(\delta_{v}\right)$ increases the energy absorption increases too, a nearly linear relationship with respect to the vertical top displacement for various levels energy absorption.

Journal of Engineering Sciences, Assiut University, Faculty of Engineering, Vol. 41, No. 2, March, 2013, E-mail address: jes@aun.edu.eg 
A. M. Ahmed et al, Static Behaviour of Different types of R.C Beam-Column Connections as Affected by Both Value of Acting Axial Normal Force and Grade of Used Concrete (Theoretical Study), pp. 321- 364

\section{Relation of max. principle stress $\left(\sigma_{1}\right)$ - maximum principle strain $\left(\varepsilon_{1}\right)$}

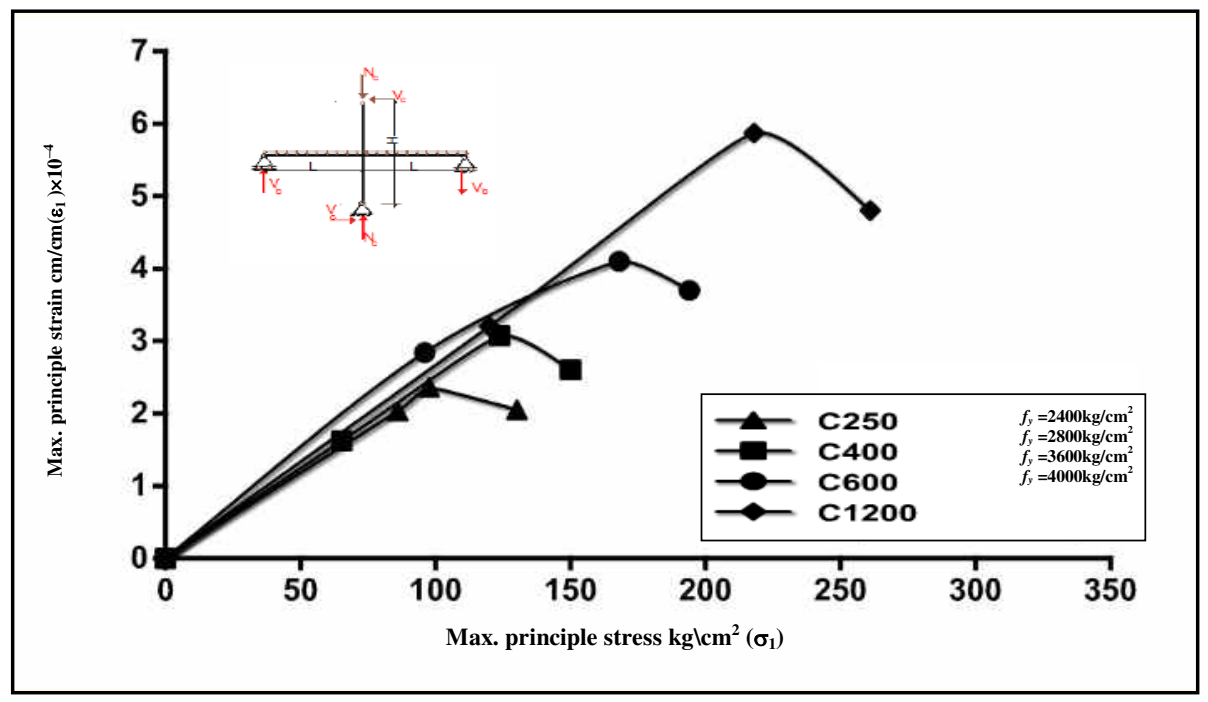

a) Relation of max. principle stress $\left(\sigma_{1}\right)$ - max. principle strain $\left(\varepsilon_{1}\right)$ for interior joint

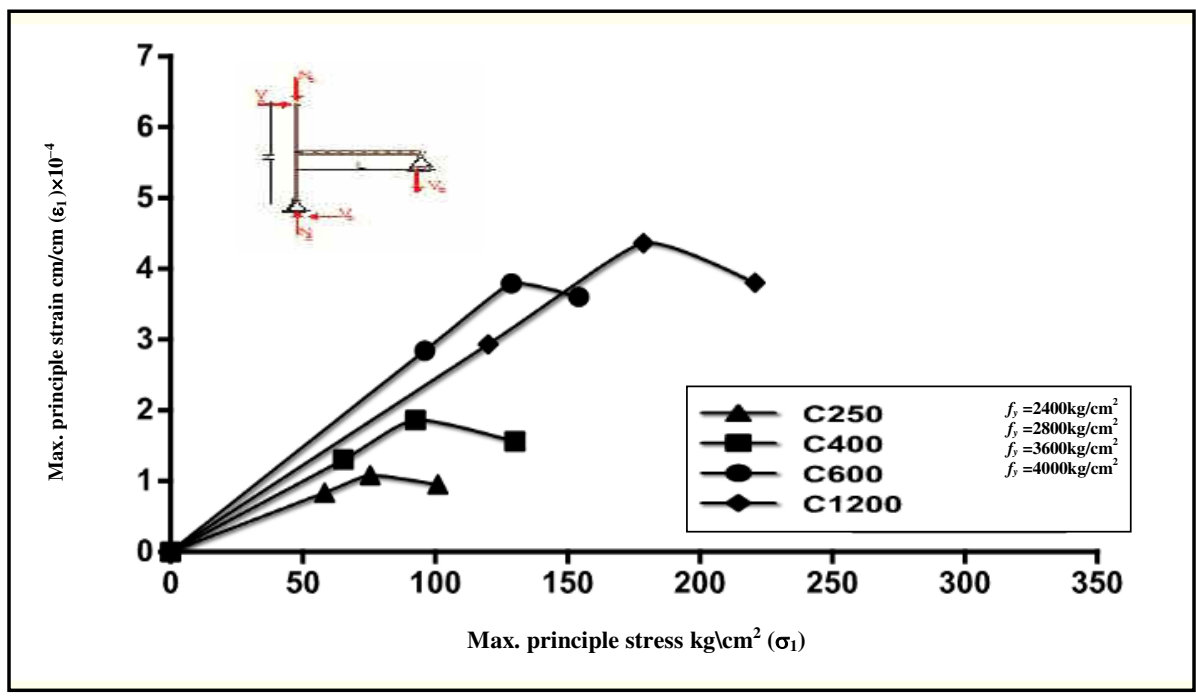

b) Relation of max. principle stress $\left(\sigma_{1}\right)$ - max. principle strain $\left(\varepsilon_{1}\right)$ exterior join

\section{Fig. 14. Relation of Maximum Principle Stress $\left(\sigma_{1}\right)$ - Maximum Principle Strain $\left(\varepsilon_{1}\right)$}

Fig.14 illustrates that axial strain increases corresponding to an axial stress increase up to the maximum stress and beyond this limit a descending branch for the diagram is noticed up to failure.

Journal of Engineering Sciences, Assiut University, Faculty of Engineering, Vol. 41, No. 2, March, 2013,E-mail address: jes@aun.edu.eg 
A. M. Ahmed et al, Static Behaviour of Different types of R.C Beam-Column Connections as Affected by Both Value of Acting Axial Normal Force and Grade of Used Concrete (Theoretical Study), pp. 321- 364

6. Relation of concrete compressive strength $\left(f_{\mathrm{c}}^{\prime}\right) \mathrm{kg} / \mathrm{cm}^{2}$ - axial cracking column loads $\left(\mathbf{N}_{\mathrm{cc}}\right)$ and ultimate column loads $\left(\mathbf{N}_{\mathrm{cu}}\right)$ :

Table 4 and Figure 15.

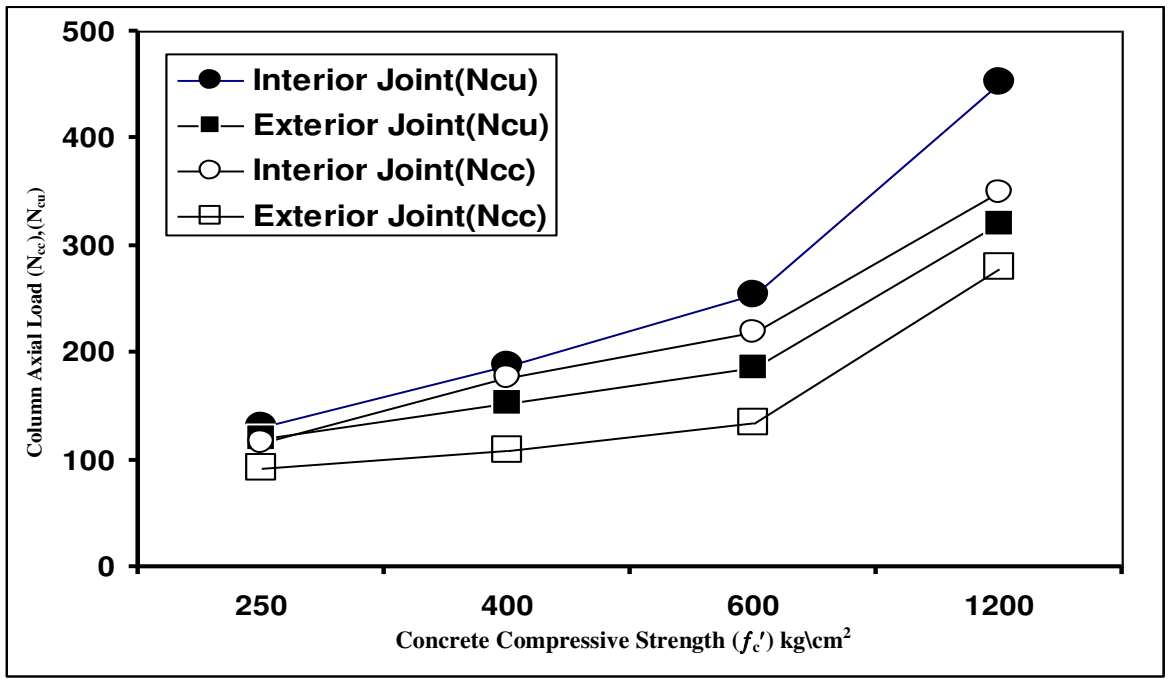

Fig. 15. The Relation of Concrete Compressive Strength $\left(f_{\mathrm{c}}{ }^{\prime}\right) \mathrm{kglcm}{ }^{2}$ Axial Column Loads $\left(\mathrm{N}_{\mathrm{c}}\right)\left(\mathrm{N}_{\mathrm{cu}}\right)$

Fig.15 illustrates that in general as the concrete compressive strength $\left(f_{\mathrm{c}}{ }^{\prime}\right)$ increases the corresponding axial applied column loads also increases, and the axial column loads $\left(\mathrm{N}_{\mathrm{cc}}\right)$ and $\left(\mathrm{N}_{\mathrm{cu}}\right)$ for interior joint is usually bigger than that for exterior joint.

\section{Table 4}

Cracking, failure loads for joint specimens:

\begin{tabular}{|c|c|c|c|}
\hline \multicolumn{2}{|c|}{$\begin{array}{l}\text { Concrete compressive } \\
\text { strength } \mathrm{kg} / \mathrm{cm}^{2}\left(f_{\mathrm{c}}^{\prime}\right)\end{array}$} & $\begin{array}{l}\text { Ultimate } \\
\operatorname{load}\left(\mathrm{N}_{\mathrm{cu}}\right)\end{array}$ & $\begin{array}{c}\text { Cracking axial } \\
\operatorname{load}\left(\mathbf{N}_{c c}\right)\end{array}$ \\
\hline \multirow{4}{*}{ 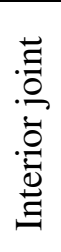 } & $\mathrm{J} 4 \mathrm{C} 250$ & 131 & 115 \\
\hline & J8 C400 & 187 & 177 \\
\hline & J12 C600 & 254 & 218 \\
\hline & J16 C1200 & 452 & 350 \\
\hline \multirow{4}{*}{ 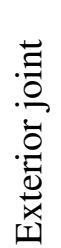 } & $\mathrm{J} 20 \mathrm{C} 250$ & 120 & 92 \\
\hline & $\mathrm{J} 24 \mathrm{C} 400$ & 152 & 109 \\
\hline & J28 C600 & 186 & 134 \\
\hline & J32 C1200 & 320 & 280 \\
\hline
\end{tabular}

Journal of Engineering Sciences, Assiut University, Faculty of Engineering, Vol. 41, No. 2, March, 2013, E-mail address: jes@aun.edu.eg 
A. M. Ahmed et al, Static Behaviour of Different types of R.C Beam-Column Connections as Affected by Both Value of Acting Axial Normal Force and Grade of Used Concrete (Theoretical Study), pp. 321- 364

\section{Analysis and discussions of the obtained results}

Variable axial load was applied gradually and constant applied lateral load was maintained at the top of the column for studied different R.C (32) joints, internal and external beam-column joints except corner (knee) joint did not have variable axial column load. The ultimate and cracking axial load was recorded as well as the maximum joint shear, axial stresses and strains were evaluated.

\subsection{W.R.T strength and stresses points of view:}

\subsubsection{Effect of concrete compressive strength $\left(f_{c}^{\prime}\right)$ on the load bearing capacity of column axial load $\left(N_{c c}\right)$ :}

It is obvious on Table 4 and Figure 16, that the axial load ratio $\left(\mathrm{N}_{\mathrm{cu}} / \mathrm{A} f_{c}\right)$ decreases with the increasing of compressive strength for both interior and exterior joint. Also, for interior joint the axial load ratio is bigger than that for exterior one. This reflects the fact that the interior joint is more effective in resisting axial load compared with that for exterior joint.

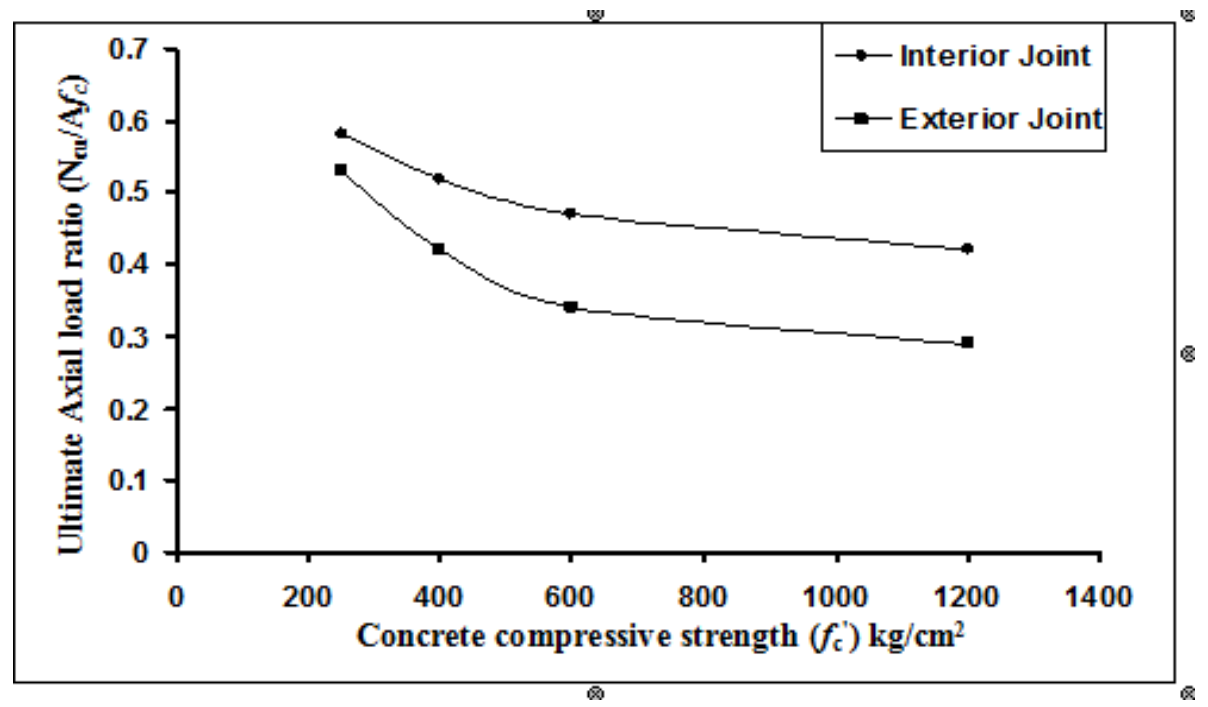

Fig.16. Relation of axial load ratio $\left(\mathrm{N}_{\mathrm{cu}} \backslash \mathrm{Ac} f c\right)$-concrete compressive strength $\left(f_{\mathrm{c}}{ }^{\prime}\right)$

\subsubsection{Effect of concrete compressive strength $\left(f_{c}^{\prime}\right)$ on joint shear stresses $\left(\tau_{j}\right)$ :}

It is shown on Table 5 and Figure 17 that a plot between the obtained joint shear stress $\left(\tau_{\mathrm{J}}\right)$ for the two studied types of joints against the used concrete grade $\left(f \mathrm{c}^{\prime}\right)$. Also it is indicated that interior joint shear stresses $\left(\tau_{\mathrm{J}}\right)$ is usually bigger than that for exterior one per $125 \%$.

The $(\mathrm{J})$ mode strength, defined by $\left(\tau_{\mathrm{j}} / f_{\mathrm{c}}^{\prime}\right)$, for the studieds joints was calculated and plotted against the corresponding compressive strength $\left(f_{\mathrm{c}}^{\prime}\right)$ as shown in Fig.18. This Figure declared that the $\left(\tau_{\mathrm{j}} / f_{\mathrm{c}}\right)$ mode strength decreases by increasing the grade of concrete. Higher values were corresponding interior joints rather than that for exterior joints. One of the findings of this study is that the joint strength coefficient $(\gamma)$, changes with the variation of the column compressive axial load. Comparing the obtained results showed that the Journal of Engineering Sciences, Assiut University, Faculty of Engineering, Vol. 41, No. 2, March, 2013, E-mail address: jes@aun.edu.eg 
A. M. Ahmed et al, Static Behaviour of Different types of R.C Beam-Column Connections as Affected by Both Value of Acting Axial Normal Force and Grade of Used Concrete (Theoretical Study), pp. 321- 364

joint shear strength coefficient has an average value of $(\gamma)=3.80$ for exterior joint, however it has as an average values of $(\gamma)=5.00$ for interior joint.

The FEMA 273 (BSSC 1997) joint shear strength coefficient is given as $(\gamma)=6$ for exterior joints without transverse beams. The ACI 352 (1991) joint shear strength coefficient for exterior joints is given as $(\gamma)=12$.

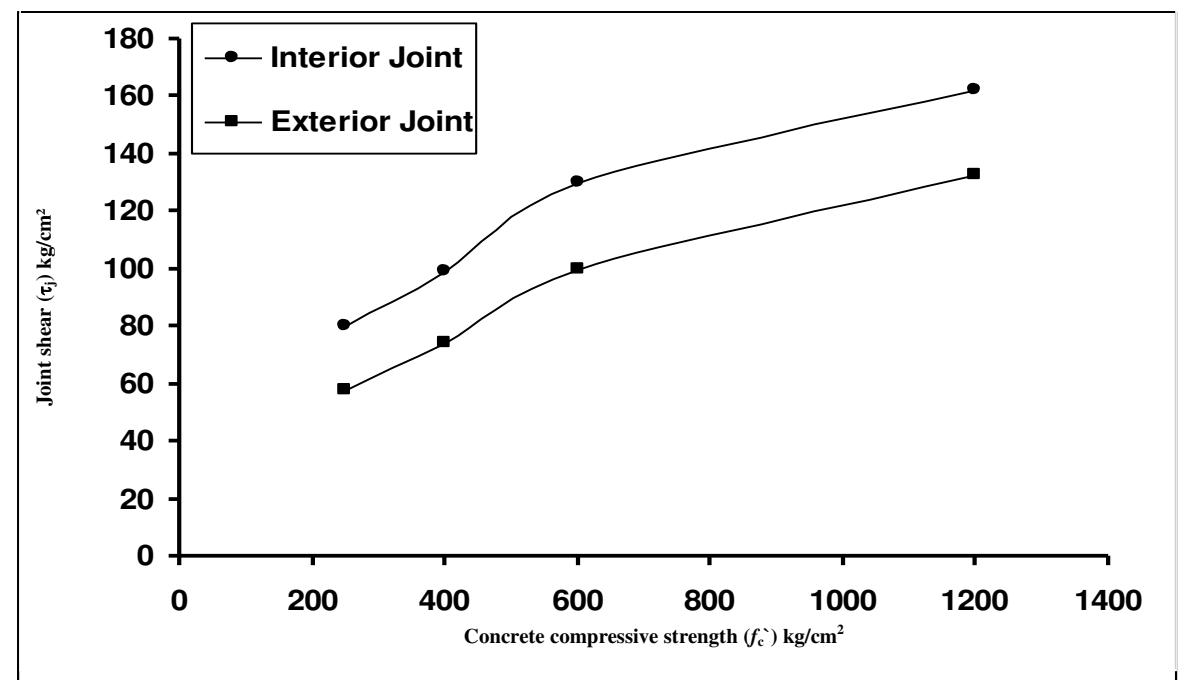

Fig.17. Relation of shear stress $\left(\tau_{\mathrm{j}}\right) \mathrm{kg} / \mathrm{cm}^{2}$ - concrete compressive strength $\left(f_{\mathrm{c}}{ }^{\prime}\right)$

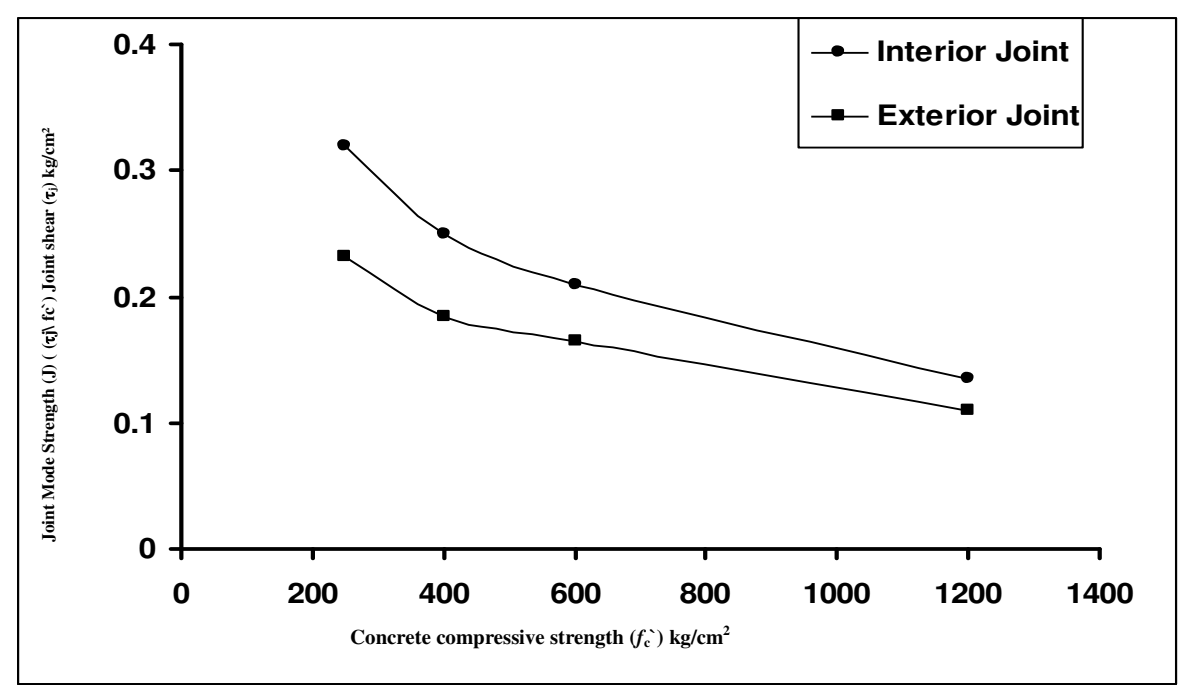

Fig.18. Relation of Concrete Compressive Strength $\left(f_{\mathrm{c}}^{\prime}\right)$ - Joint Mode Strength $(\mathbf{J})$ $\left(\tau_{\mathrm{j}} \backslash f_{\mathrm{c}}{ }^{\prime}\right)$ 
A. M. Ahmed et al, Static Behaviour of Different types of R.C Beam-Column Connections as Affected by Both Value of Acting Axial Normal Force and Grade of Used Concrete (Theoretical Study), pp. 321- 364

\section{Table 5}

Test results of beam column joint with axial load failure.

\begin{tabular}{|c|c|c|c|c|c|c|c|c|c|c|c|c|}
\hline \multicolumn{2}{|c|}{ Joint test } & $\begin{array}{l}\text { Ultimate } \\
\operatorname{load}\left(\mathrm{N}_{\mathrm{cu}}\right)\end{array}$ & $\begin{array}{c}\text { Cracking } \\
\text { axial } \\
\operatorname{load}\left(\mathbf{N}_{\mathrm{cc}}\right)\end{array}$ & $\begin{array}{l}\left(\mathbf{N}_{\mathrm{cu}}\right) / \\
\mathbf{A c F c}\end{array}$ & $\begin{array}{c}\text { Top Axial } \\
\text { Displace- } \\
\text { ment } \\
\operatorname{mm}(\delta v)\end{array}$ & $\begin{array}{c}\text { Max. } \\
\text { joint } \\
\text { shear } \\
\text { stress } \\
\left(\tau_{\mathbf{j}}\right) \\
\mathbf{k g} / \mathrm{cm}^{2} \\
\end{array}$ & $\begin{array}{c}\text { Max. } \\
\text { principle } \\
\text { strain } \\
\mathrm{cm} / \mathrm{cm} \\
\left(\varepsilon_{1} \times 10^{-4}\right)\end{array}$ & $\begin{array}{c}\text { Joint } \\
\text { strength } \\
\text { coeff. } \\
\gamma=\tau_{j} \backslash \sqrt{ } f_{c}^{\prime}\end{array}$ & $\begin{array}{c}\text { Energy } \\
\text { Absorbed } \\
\text { ton } \times \mathbf{m m}\end{array}$ & $\begin{array}{c}\text { joint shear } \\
\text { stress } \backslash \\
\text { compressi } \\
\text { ve stress } \\
(\mathrm{J})=\left(\tau_{\mathrm{j}} \backslash f_{\mathrm{c}}{ }^{\prime}\right)\end{array}$ & $\begin{array}{c}\text { Max. } \\
\text { principal } \\
\operatorname{stress}\left(\sigma_{1}\right) \\
\mathbf{k g} / \mathrm{cm}^{2}\end{array}$ & $\begin{array}{c}\text { Joint } \\
\text { bond } \\
\text { stress } \\
\left(\mathbf{k g} \backslash \mathbf{c m}^{2}\right) \\
\left(\mu_{\mathrm{b}}\right)\end{array}$ \\
\hline \multirow{4}{*}{ 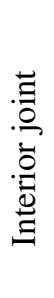 } & $\mathrm{C} 250$ & 131 & 115 & 0.58 & 24.50 & 80.04 & 2.85 & 5.06 & 2764 & 0.32 & 24.11 & 12.00 \\
\hline & $\mathrm{C} 400$ & 187 & 177 & 0.52 & 40.22 & 99.31 & 3.66 & 4.97 & 4730 & 0.25 & 43.02 & 13.50 \\
\hline & C600 & 254 & 218 & 0.47 & 44.08 & 129.76 & 4.70 & 5.27 & 6080 & 0.21 & 67.87 & 19.45 \\
\hline & C1200 & 452 & 350 & 0.42 & 65.00 & 162 & 6.10 & 4.67 & 9752 & 0.13 & 190 & 24.20 \\
\hline \multirow{4}{*}{ 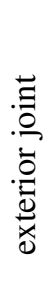 } & $\mathrm{C} 250$ & 120 & 92 & 0.53 & 18.80 & 58.06 & 1.55 & 3.67 & 1179 & 0.23 & 69.22 & 8.20 \\
\hline & $\mathrm{C} 400$ & 152 & 109 & 0.42 & 32.63 & 74.20 & 2.86 & 3.704 & 2508 & 0.18 & 89 & 11.05 \\
\hline & C600 & 186 & 134 & 0.34 & 36.25 & 99.54 & 4.20 & 4.04 & 3348 & 0.16 & 120 & 14.85 \\
\hline & $\mathrm{C} 1200$ & 320 & 280 & 0.29 & 53.50 & 132.84 & 5.80 & 3.84 & 6480 & 0.11 & 166 & 18.20 \\
\hline
\end{tabular}


A. M. Ahmed et al, Static Behaviour of Different types of R.C Beam-Column Connections as Affected by Both Value of Acting Axial Normal Force and Grade of Used Concrete (Theoretical Study), pp. 321- 364

\subsubsection{Effect of column axial load ratio $\left(N_{c} / A_{c} F_{c}\right) \%$ on joint shear stresses $\left(\tau_{J}\right)$ :}

Figs. 19(a) and (b), and Tables 6 (a) and (b) show the relation between the axial load ratio $\left(\mathrm{N}_{\mathrm{c}} / \mathrm{A}_{\mathrm{c}} f_{\mathrm{c}}{ }^{\prime} \%\right)$ on the induced shear stress $\left(\tau_{\mathrm{j}}\right)$ for different grades of concrete for the studied joints. At Interior and Exterior joints higher nominal shear stress $\left(\tau_{\mathrm{j}}\right)$ both are not affected by axial load ratio $\left(\mathrm{N}_{\mathrm{c}} / \mathrm{A}_{\mathrm{c}} f_{{ }_{\mathrm{c}}} \%\right)$ for $\mathrm{C} 250,400,600$ as given by NZS 3101 (1995) Code but for grade $\mathrm{C} 1200$ nominal shear stress $\left(\tau_{\mathrm{j}}\right)$ slightly decreases as the axial load ratio $\left(\mathrm{N}_{\mathrm{c}} / \mathrm{A}_{\mathrm{c}} f_{\mathrm{c}}{ }^{\prime} \%\right)$ increases as mentioned by EN3101 (1995) Code.

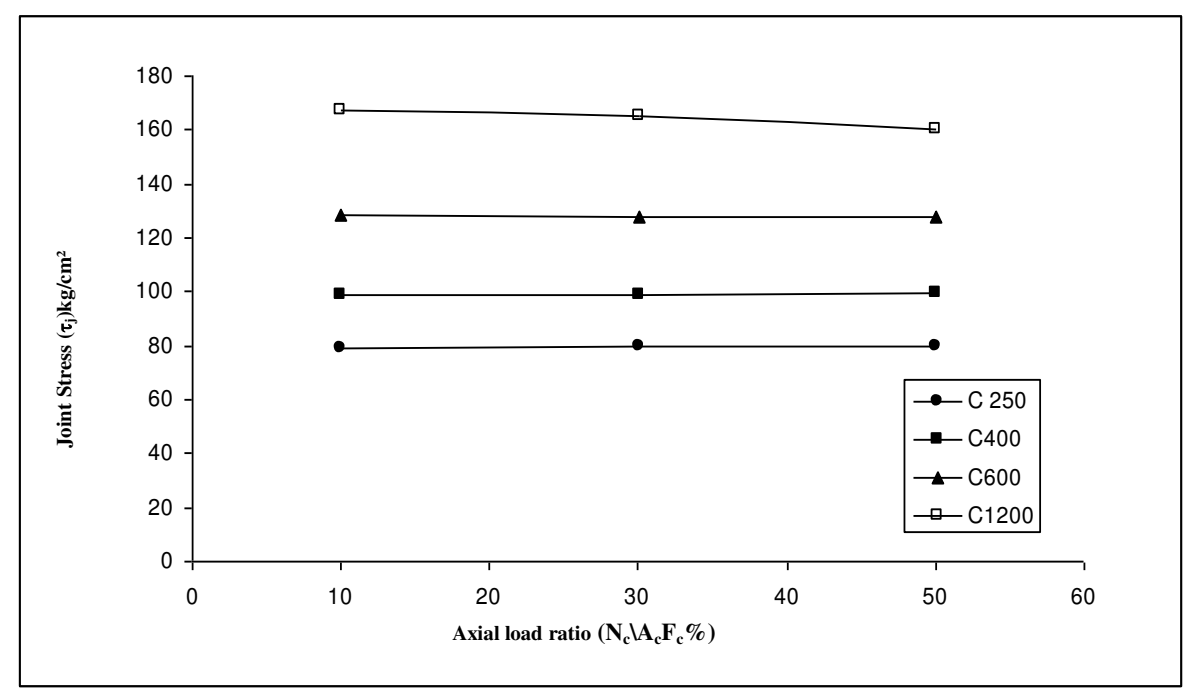

Fig.19.a. Relation of axial load ratio $\left(\mathrm{N}_{\mathrm{c}} / \mathrm{A}_{\mathrm{c}} \mathrm{F}_{\mathrm{c}} \%\right)$ - joint shear stress $\left(\tau_{\mathrm{j}}\right) \mathrm{kg} / \mathrm{cm}^{2}$ for interior joints

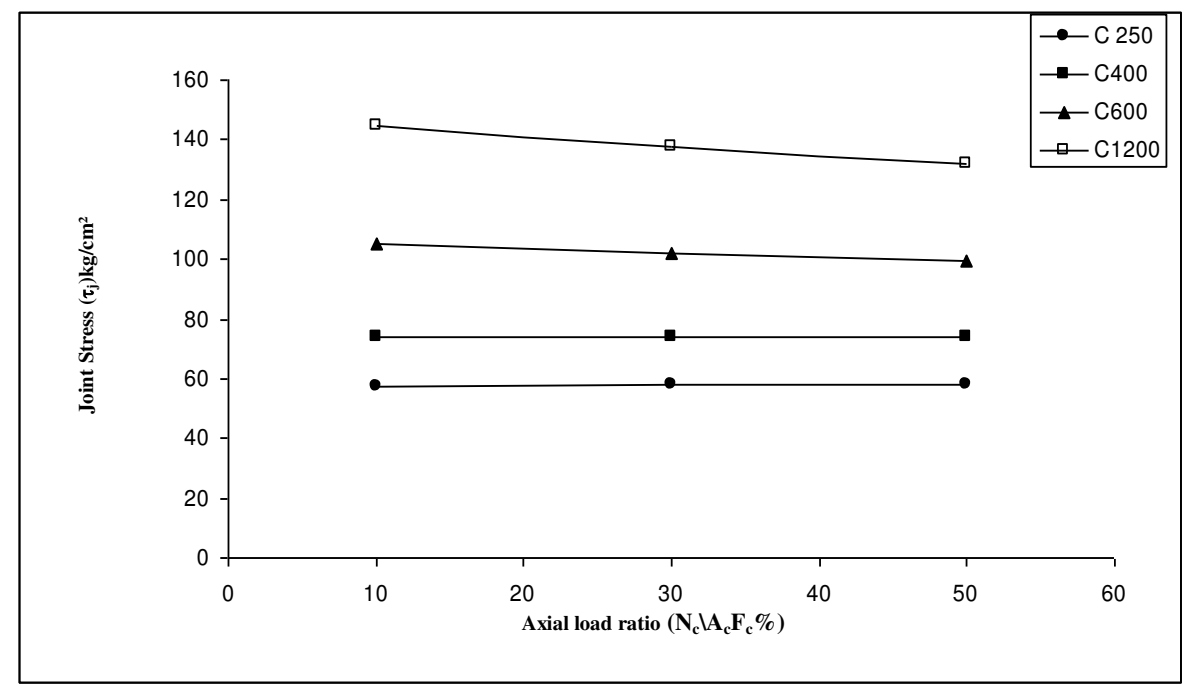

Fig.19.b. Relation of axial load ratio $\left(\mathrm{N}_{\mathrm{c}} / \mathrm{A}_{\mathrm{c}} \mathrm{F}_{\mathrm{c}} \%\right)$ - joint shear stress $\left(\tau_{\mathrm{j}}\right) \mathrm{kg} \backslash \mathrm{cm}{ }^{2}$ for exterior joints 
A. M. Ahmed et al, Static Behaviour of Different types of R.C Beam-Column Connections as Affected by Both Value of Acting Axial Normal Force and Grade of Used Concrete (Theoretical Study), pp. 321- 364

8.1.4. Effect of concrete compressive strength $\left(f_{c}^{\prime}\right)$ on bond strength $\left(\mu_{b}\right)$ of beam reinforcement:

A maximum bond stress $\left(u_{b}\right)$ of beam reinforcement over the column width was estimated by assuming simultaneous yielding of the beam reinforcement in tension and compression at the two faces of the joint. Table 5 and Figure 20 show the relation between concrete compressive strength $\left(f_{\mathrm{c}}\right)$ on bond strength $\left(\mu_{\mathrm{b}}\right)$ for the studied joints. For both interior and exterior joints. The increase of concrete grade is usually accompanied by an increase in the induced bond Strength $\left(\mu_{\mathrm{b}}\right)$. Figure 21 indicates that the increase of concrete grade is usually accompanied by a constant ratio for induced ratio of joint shear stress/ bond strength $\left(\tau_{\mathrm{j}} / \mu_{\mathrm{b}}\right)$ disregarding the type of joint. i.e. Interior and exterior joints usually possess the same values of the induced ratio of $\left(\tau_{j} / \mu_{b}\right)$ for any grade of concrete.

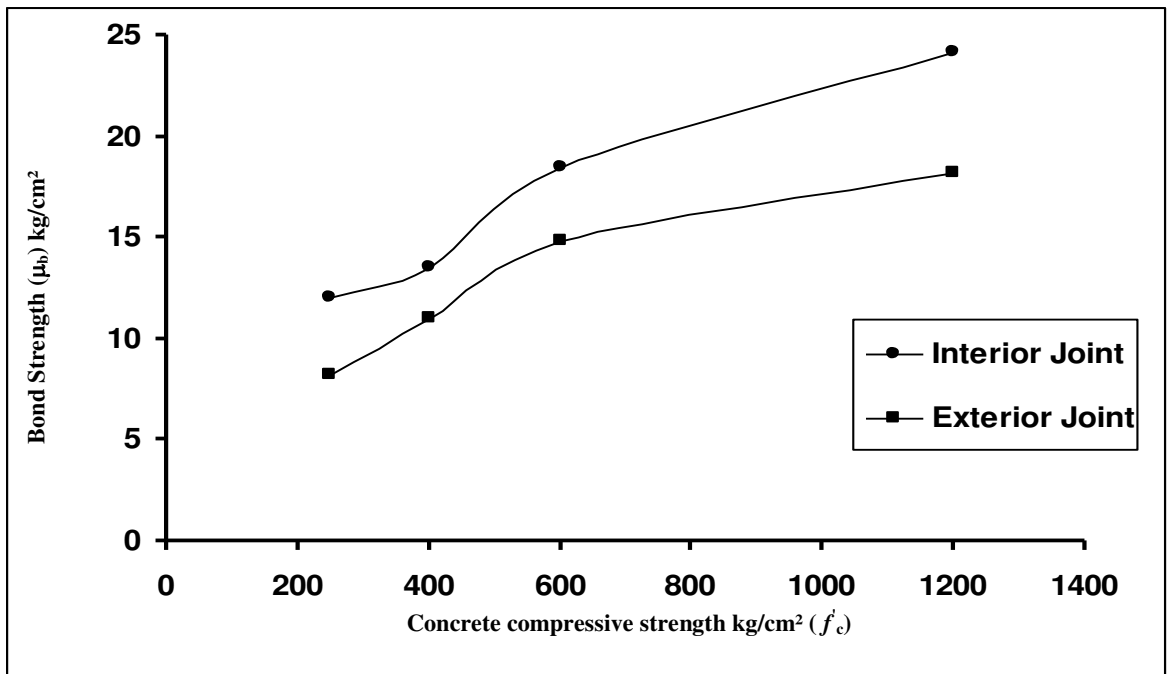

Fig. 20. Relation of concrete compressive strength $\left(f_{\mathrm{c}}\right)$ - bond strength $\left(\mu_{\mathrm{b}}\right)$

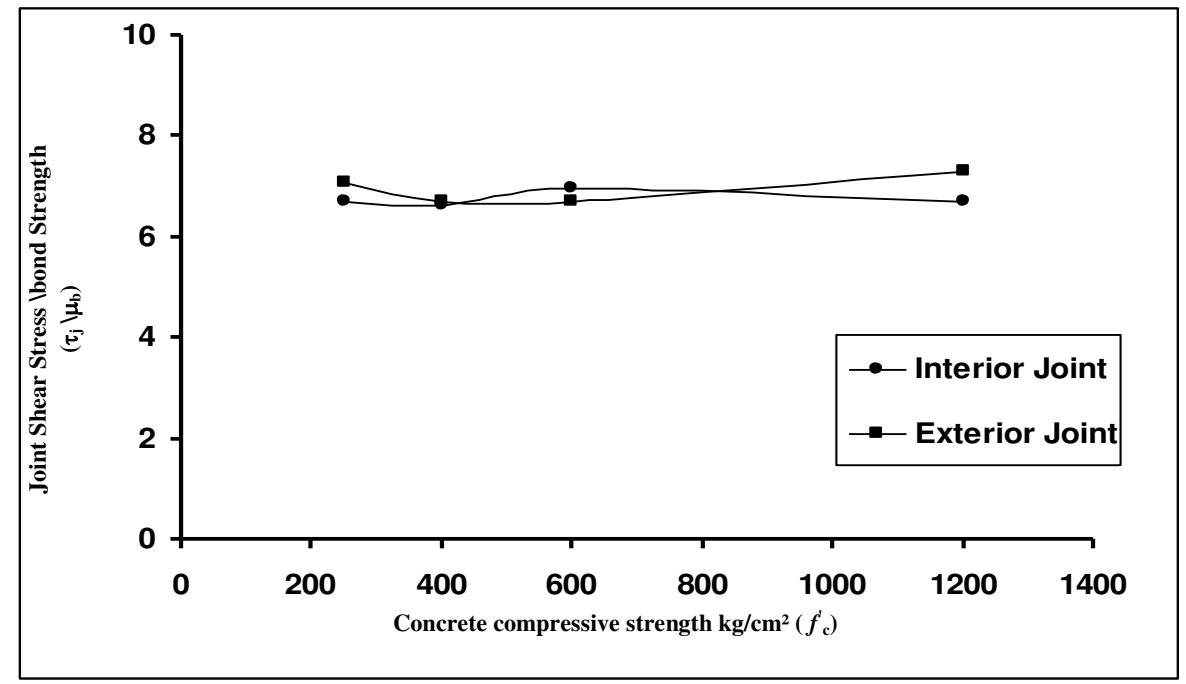

Fig. 21. Relation of concrete compressive strength $\left(f_{\mathrm{c}}^{\prime}\right)$ - joint shear stress lbond strength $\left(\tau_{\mathrm{j}} / \mu_{\mathrm{b}}\right)$ for studied joints

Journal of Engineering Sciences, Assiut University, Faculty of Engineering, Vol. 41, No. 2, March, 2013, E-mail address: jes@aun.edu.eg 
A. M. Ahmed et al, Static Behaviour of Different types of R.C Beam-Column Connections as Affected by Both Value of Acting Axial Normal Force and Grade of Used Concrete (Theoretical Study), pp. 321- 364

8.1.5. Effect of concrete compressive strength $\left(f_{c}^{\prime}\right)$ on axial principal stress $\left(\sigma_{l}\right)$ $\mathrm{kg} / \mathrm{cm}^{2}$ :

Figure 22 and Table 7 show maximum principle stresses values of the joint concrete at the maximum strength for ultimate axial loading for both interior and exterior joint. The increase of concrete compressive strength is usually accompanied with an effective increase on the induced principle stresses for both types of joints.

Figure 23 and Table 7 indicate that the increase of concrete grade is usually accompanied by a decrease in the induced ratio of $\left(\sigma_{1} / f_{\mathrm{c}}^{\prime}\right)$ disregarding the type of joint. Also it is interesting to note that interior joint usually posses higher values of the induced ratio of $\left(\sigma_{1} / f_{\mathrm{c}}^{\prime}\right)$ for any grade of concrete. Also, Figure 23 indicates that the rate of decrease of the induced ratio of $\left(\sigma_{1} / f_{\mathrm{c}}^{\prime}\right)$ for $(\mathrm{C} 250-\mathrm{C} 600)$ different rather than the induced ratio of $\left(\sigma_{1} / f_{\mathrm{c}}^{\prime}\right)$ for $(\mathrm{C} 600-\mathrm{C} 1200)$ for all kinds of studied joints.

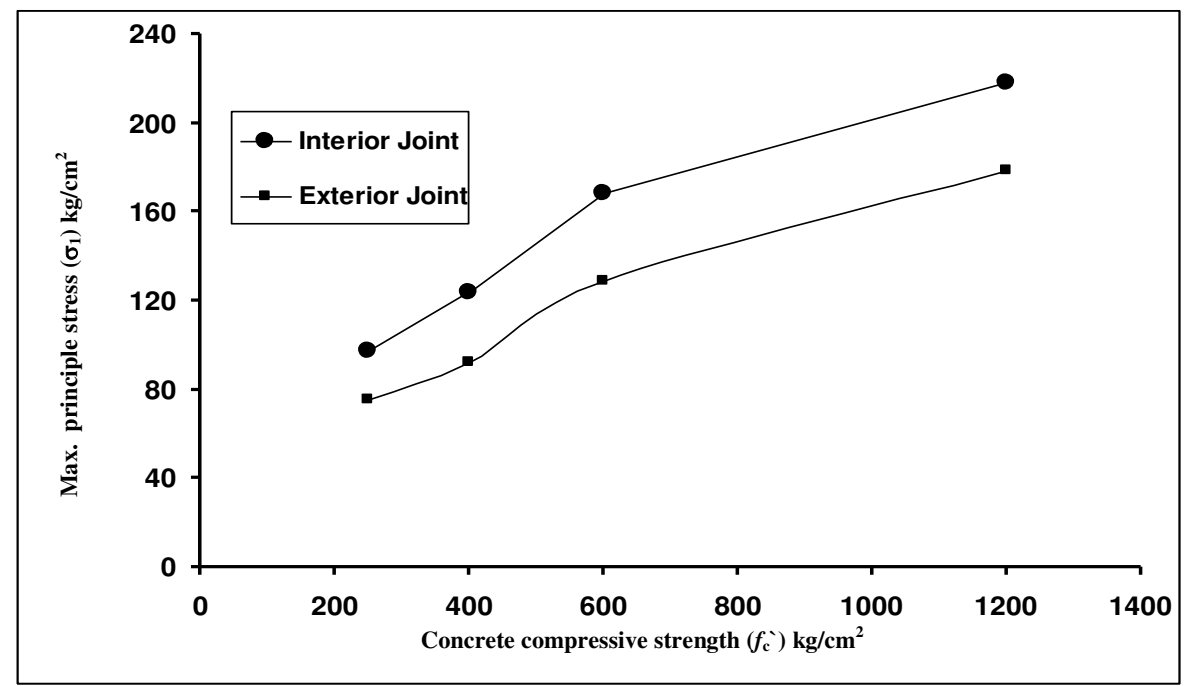

Fig. 22. Relation of concrete compressive strength $\left(f_{\mathrm{c}}{ }^{\prime}\right) \mathrm{kg} / \mathrm{cm}$ axial principal stress $\left(\sigma_{1}\right)$

Figures 24.a, 24.b and Tables 6-a and 6-b illustrate the relation between the axial load ratio $\left(\mathrm{N}_{\mathrm{c}} / \mathrm{A}_{\mathrm{c}} f_{\mathrm{c}}{ }^{\prime} \%\right)$ on principle axial stress $\left(\sigma_{1}\right)$ at different grades of concrete for the studied joints. For both interior and exterior joints the maximum induced principle axial stresses $\left(\sigma_{1}\right)$ are not affected by the value of the acting axial load ratio, but significantly affected by both the type of joint and the grade of used concrete. 
A. M. Ahmed et al, Static Behaviour of Different types of R.C Beam-Column Connections as Affected by Both Value of Acting Axial Normal Force and Grade of Used Concrete (Theoretical Study), pp. $321-364$

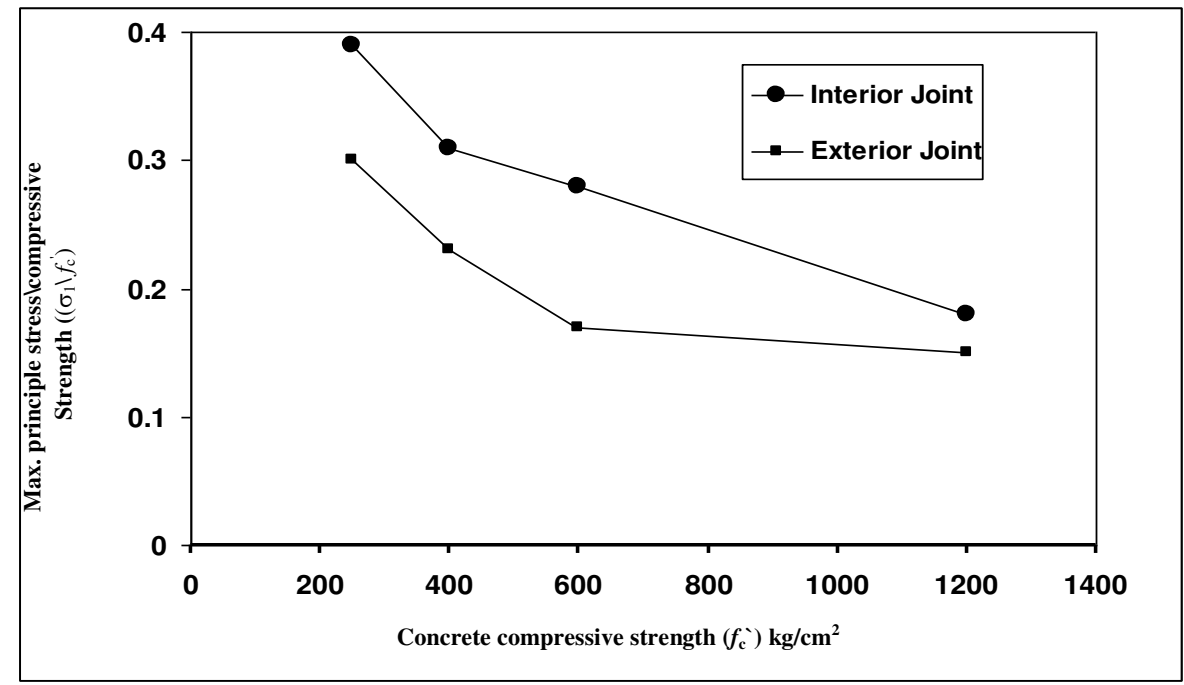

Fig. 23. Relation of concrete compressive strength $\left(f_{\mathrm{c}}^{\prime}\right)$ - maximum principle stress/concrete compressive strength $\left(\sigma_{1 /} f_{\mathrm{c}}\right)$ for studied joints

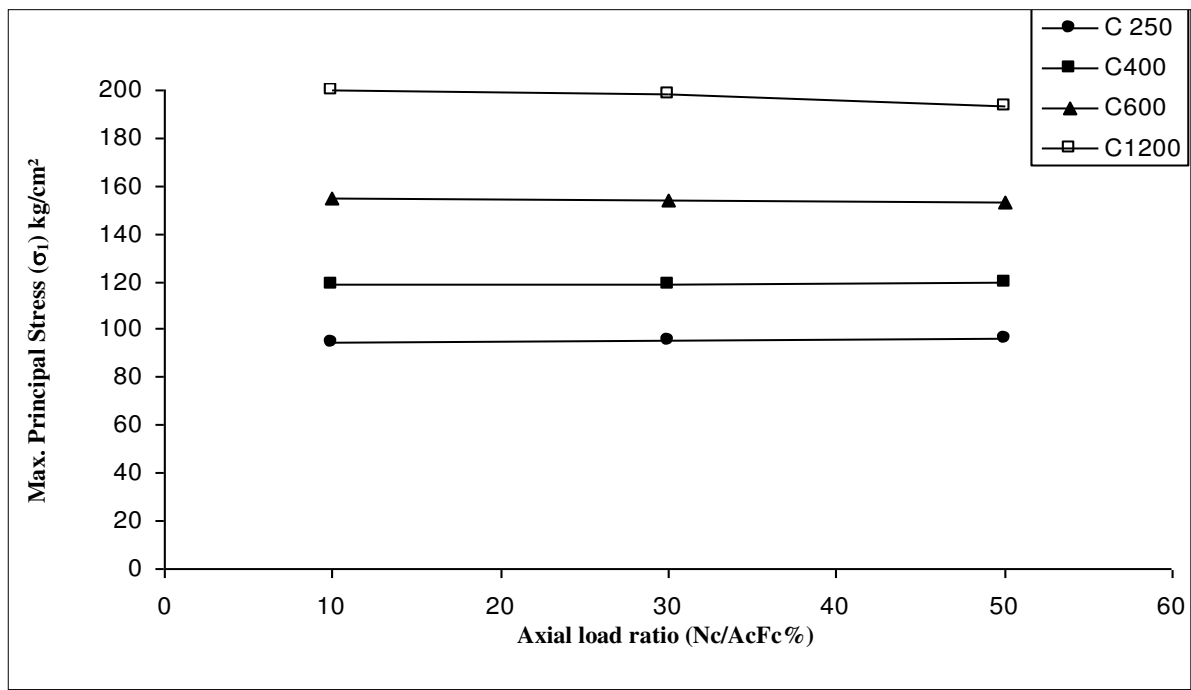

Fig. 24.a. Relation of axial load ratio $\left(\mathrm{N}_{\mathrm{c}} / \mathrm{A}_{\mathrm{c}} \mathrm{F}_{\mathrm{c}} \%\right)$ - maximum principal axial stress $\left(\sigma_{1}\right) \mathrm{kg} / \mathrm{cm}^{2}$ for interior joints 
A. M. Ahmed et al, Static Behaviour of Different types of R.C Beam-Column Connections as Affected by Both Value of Acting Axial Normal Force and Grade of Used Concrete (Theoretical Study), pp. 321- 364

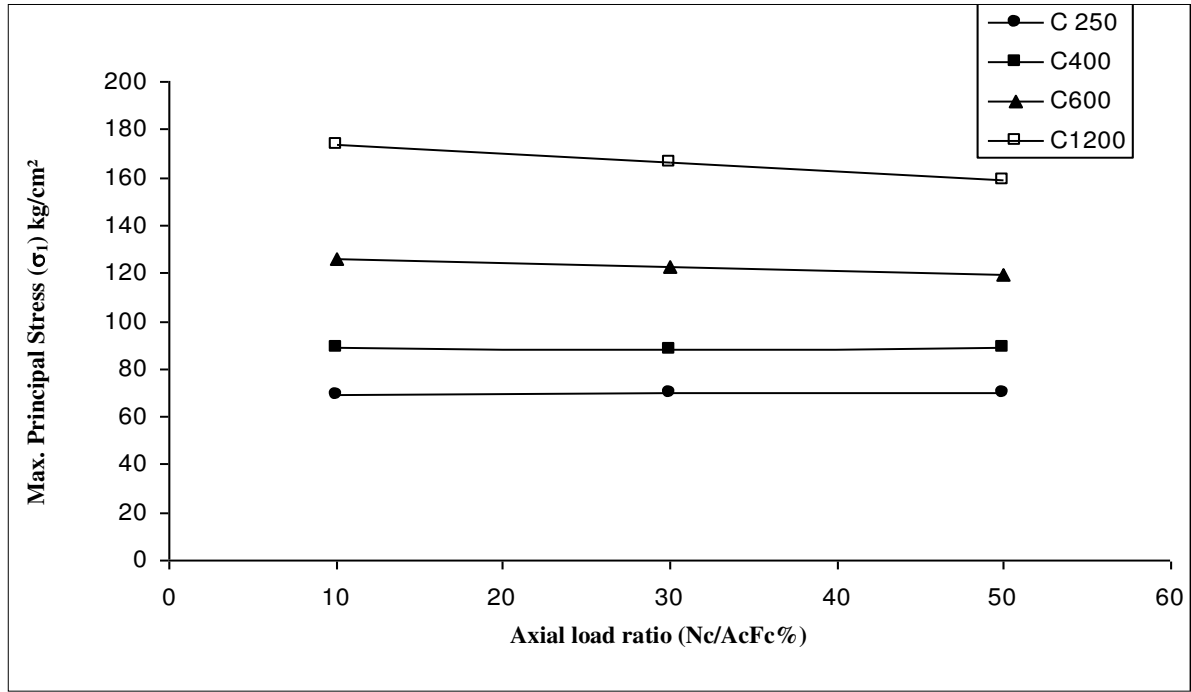

Fig. 24.b. Relation of axial load ratio $\left(\mathrm{N}_{\mathrm{c}} / \mathrm{A}_{\mathrm{c}} \mathrm{F}_{\mathrm{c}} \%\right)$ - maximum principal axial stress $\left(\sigma_{1}\right) \mathrm{kg} / \mathrm{cm}^{2}$ for exterior joints

\section{Table 6}

Effect of column axial load ratio $\left(\mathrm{N}_{\mathrm{c}} / \mathrm{A}_{\mathrm{c}} \mathrm{F}_{\mathrm{c}}\right)$ on shear and axial stresses $\left(\tau_{\mathrm{J}}, \sigma_{1}\right)$ :

Table (6-a)

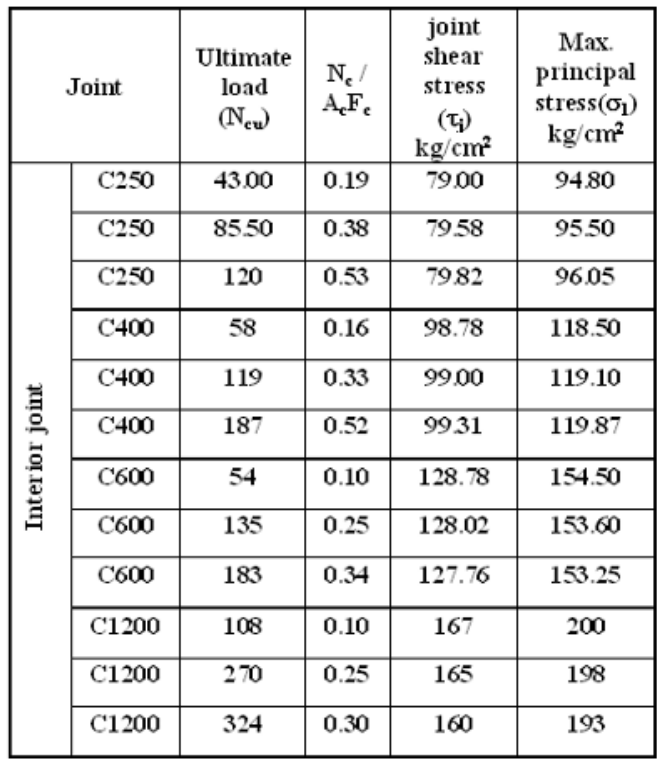

Table (6-b)

\begin{tabular}{|c|c|c|c|c|c|}
\hline \multicolumn{2}{|c|}{ Joint } & $\begin{array}{c}\text { Ultimate } \\
\text { load } \\
\left(\mathrm{N}_{\mathrm{ew}}\right)\end{array}$ & $\begin{array}{c}\mathrm{N}_{\mathrm{c}} / \\
\mathrm{AcFc}\end{array}$ & $\begin{array}{c}\text { joint shear } \\
\text { stress } \\
\left(\tau_{i}\right) \mathrm{kg} / \mathrm{cm}^{2}\end{array}$ & $\begin{array}{c}\text { Max. } \\
\text { principal } \\
\text { stress }\left(\sigma_{1}\right) \\
\mathrm{kg} / \mathrm{cm}^{2}\end{array}$ \\
\hline \multirow{12}{*}{ 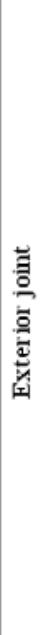 } & $\mathrm{C} 250$ & 3500 & 0.19 & 57.68 & 69.22 \\
\hline & $\mathrm{C} 250$ & 86 & 0.38 & 5798 & 69.67 \\
\hline & $\mathrm{C} 250$ & 120 & 0.53 & 58.06 & 69.56 \\
\hline & $\mathrm{C} 400$ & 36 & 0.16 & 7396 & 88.75 \\
\hline & $\mathrm{C} 400$ & 119 & 0.33 & 74.00 & 88.02 \\
\hline & $\mathrm{C} 400$ & 187 & 0.52 & 74.20 & 89.05 \\
\hline & $\mathrm{C} 600$ & 54 & 0.10 & 105.32 & 126 \\
\hline & $\mathrm{C} 600$ & 135 & 0.25 & 101.87 & 123 \\
\hline & $\mathrm{C} 600$ & 186 & 0.34 & 99.54 & 119.40 \\
\hline & $\mathrm{C} 1200$ & 108 & 0.10 & 145 & 174 \\
\hline & $\mathrm{C} 1200$ & 270 & 0.25 & 138.25 & 166 \\
\hline & $\mathrm{C} 1200$ & 320 & 0.30 & 132.84 & 159.30 \\
\hline
\end{tabular}


A. M. Ahmed et al, Static Behaviour of Different types of R.C Beam-Column Connections as Affected by Both Value of Acting Axial Normal Force and Grade of Used Concrete (Theoretical Study), pp. 321- 364

Table 7

Effect of Concrete Compressive Strength $\left(f_{c}^{\prime}\right)$ on stresses $\left(\sigma_{1}\right),\left(\tau_{\mathfrak{j}}\right)$ and strains

\begin{tabular}{|c|c|c|c|c|c|c|c|c|c|c|}
\hline & Joint & $\begin{array}{l}\text { Ultimate } \\
\operatorname{load}\left(\mathbf{N}_{\mathrm{cu}}\right)\end{array}$ & $\begin{array}{l}\left(\mathbf{N}_{\mathrm{cu}}\right) / \\
\mathbf{A c F c}\end{array}$ & $\begin{array}{c}\text { Max. joint } \\
\text { shear } \\
\text { stress } \tau_{\mathrm{j}} \\
\mathbf{k g} / \mathrm{cm}^{2}\end{array}$ & $\begin{array}{c}\text { Max. } \\
\text { principle } \\
\text { strain } \\
\mathbf{c m} / \mathbf{c m} \\
\left(\varepsilon_{1} \times 10^{-4}\right)\end{array}$ & 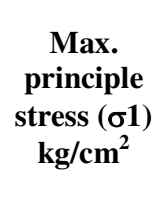 & $\begin{array}{c}\text { Energy } \\
\text { Absorbed } \\
\text { (E.A) } \\
\text { ton } \times \mathbf{m}\end{array}$ & $\begin{array}{c}\text { Max. } \\
\text { principle } \\
\text { stress } \backslash \\
\text { Compressive } \\
\text { stress }\left(\sigma_{1} \backslash f_{\mathrm{c}}{ }^{\prime}\right)\end{array}$ & $\begin{array}{c}\text { Max. pr. } \\
\text { stress } \backslash \text { Max. } \\
\text { pr. strain } \\
\left(\sigma_{1} \mid \varepsilon_{1} \times\right. \\
\mathbf{1 0}^{4} \mathbf{k g} / \mathbf{c m}^{2}\end{array}$ & $\begin{array}{c}\text { shear stress } \\
\text { bond stress } \\
\left(\tau_{\mathrm{j}} \backslash \mu_{\mathrm{b}}\right)\end{array}$ \\
\hline \multirow{4}{*}{ 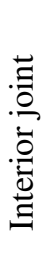 } & $\mathrm{C} 250$ & 131 & 0.58 & 80.04 & 2.85 & 97.60 & 2764 & 0.39 & 34.24 & 6.70 \\
\hline & $\mathrm{C} 400$ & 187 & 0.52 & 99.31 & 3.66 & 123.75 & 4730 & 0.31 & 33.88 & 6.62 \\
\hline & C600 & 254 & 0.47 & 129.76 & 4.70 & 168 & 6080 & 0.28 & 35.74 & 6.97 \\
\hline & $\mathrm{C} 1200$ & 452 & 0.42 & 162 & 6.10 & 218 & 9752 & 0.18 & 35.74 & 6.69 \\
\hline \multirow{4}{*}{ 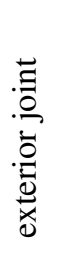 } & $\mathrm{C} 250$ & 120 & 0.53 & 58.06 & 1.55 & 75.46 & 1179 & 0.30 & 48.68 & 7.07 \\
\hline & $\mathrm{C} 400$ & 152 & 0.42 & 74.20 & 2.86 & 92.49 & 2508 & 0.23 & 32.33 & 6.69 \\
\hline & C600 & 186 & 0.34 & 99.54 & 4.20 & 128.7 & 3348 & 0.17 & 30.64 & 6.70 \\
\hline & C1200 & 320 & 0.29 & 132.84 & 5.80 & 178.6 & 6480 & 0.15 & 30.79 & 7.29 \\
\hline
\end{tabular}


A. M. Ahmed et al, Static Behaviour of Different types of R.C Beam-Column Connections as Affected by Both Value of Acting Axial Normal Force and Grade of Used Concrete (Theoretical Study), pp. 321- 364

\subsection{W.R.T deformations and strains points of view:}

\subsubsection{Effect of concrete compressive strength $\left(f_{c}^{\prime}\right)$ on (axial displacement $m m(\delta v)$ :}

Table 8 and Figure 25 illustrate that the vertical displacement increases with the decrease of concrete compressive strength. Finally vertical displacement is bigger for exterior joint than that for interior joint with $135 \%$.

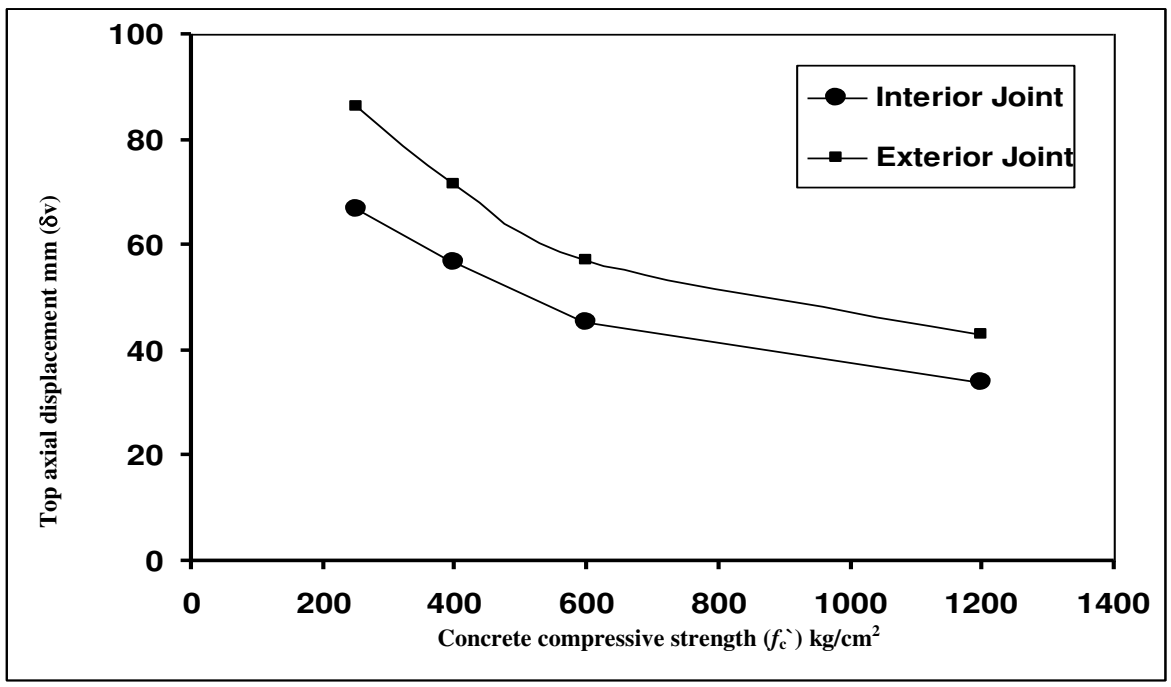

Fig. 25. Relation of top axial displacement $m m(\delta v)$ - concrete compressive strength

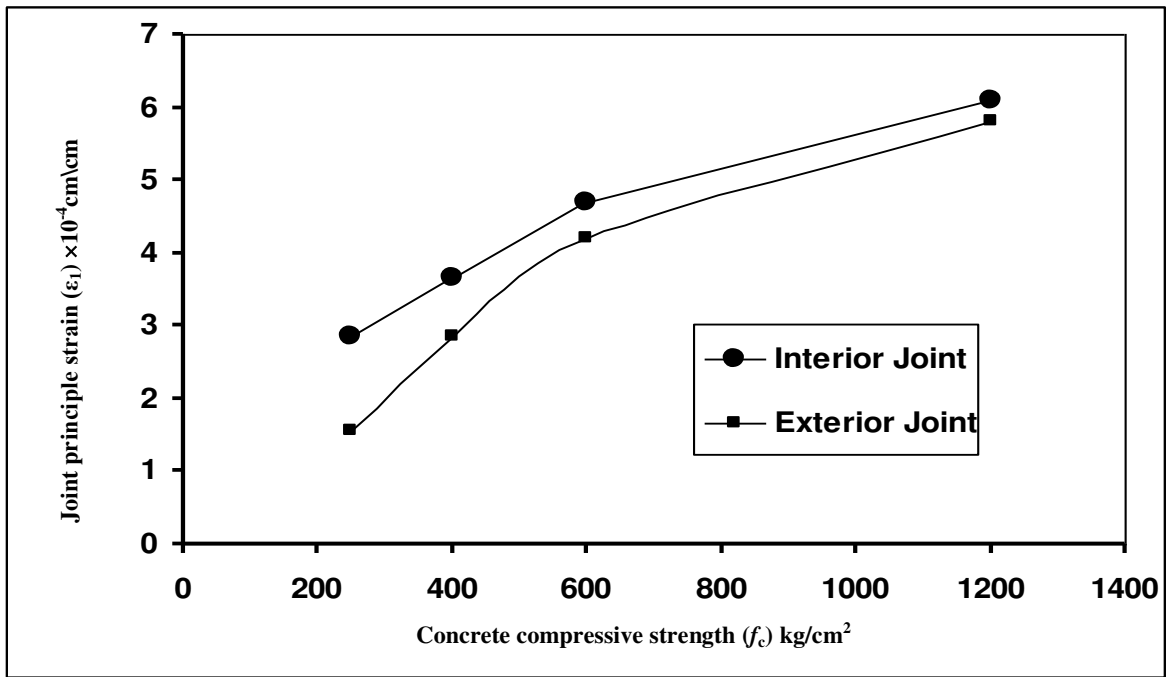

Fig.26. Relation joint principle strain $\left(\varepsilon_{1}\right)$ - concrete compressive strength $\left(f c^{\prime}\right)$ $\mathrm{kg} / \mathrm{cm}$

Journal of Engineering Sciences, Assiut University, Faculty of Engineering, Vol. 41, No. 2, March, 2013,E-mail address: jes@aun.edu.eg 
A. M. Ahmed et al, Static Behaviour of Different types of R.C Beam-Column Connections as Affected by Both Value of Acting Axial Normal Force and Grade of Used Concrete (Theoretical Study), pp. 321- 364

\subsubsection{Effect of concrete compressive strength $\left(f_{c}^{\prime}\right)$ on axial strain $\left(\varepsilon_{1}\right) \mathrm{cm} / \mathrm{cm}$ :}

Figure 26 and Table 7 indicate that the increase of concrete grade is usually accompanied by an increase in the induced principle strains $\left(\varepsilon_{1}\right)$ disregarding the type of joint. Also it is interesting to note that interior joint usually possesses higher values of maximum induced principle strain $\left(\varepsilon_{1}\right)$ for any grade of concrete. Finally it is indicated that the rate of increase of maximum principle strain $\left(\varepsilon_{1}\right)$ with respect to the increase of concrete grade is more or less equal for both two studied types of joints.

Figure 27 and Table 7 illustrate the relation between the concrete grade $\left(f_{\mathrm{c}}{ }^{\prime}\right)$ and the corresponding induced ratio of maximum principle stress / maximum principle strain $\left(\sigma_{1} / \varepsilon_{1}\right)$. Figure 27 indicates that the increase of concrete grade $\left(f_{\mathrm{c}}{ }^{\prime}\right)$ is usually accompanied by more or less constant rate of $\left(\sigma_{1} / \varepsilon_{1}\right)$ for interior joints, however concrete compressive strength $\left(f_{\mathrm{c}}{ }^{\prime}\right)$ has a slight effect to decrease $\left(\sigma_{1} / \varepsilon_{1}\right)$ for exterior joint. This means that both interior and exterior joint posses approximately the same value of induced ratio $\left(\sigma_{1} / \varepsilon_{1}\right)$ against the corresponding values of concrete compressive strength.

Table 8

Effect of column axial load $\left(\mathrm{N}_{\mathrm{c}}\right)$ on top axial displacement $\mathrm{mm}(\delta \mathrm{v})$ (Case B).

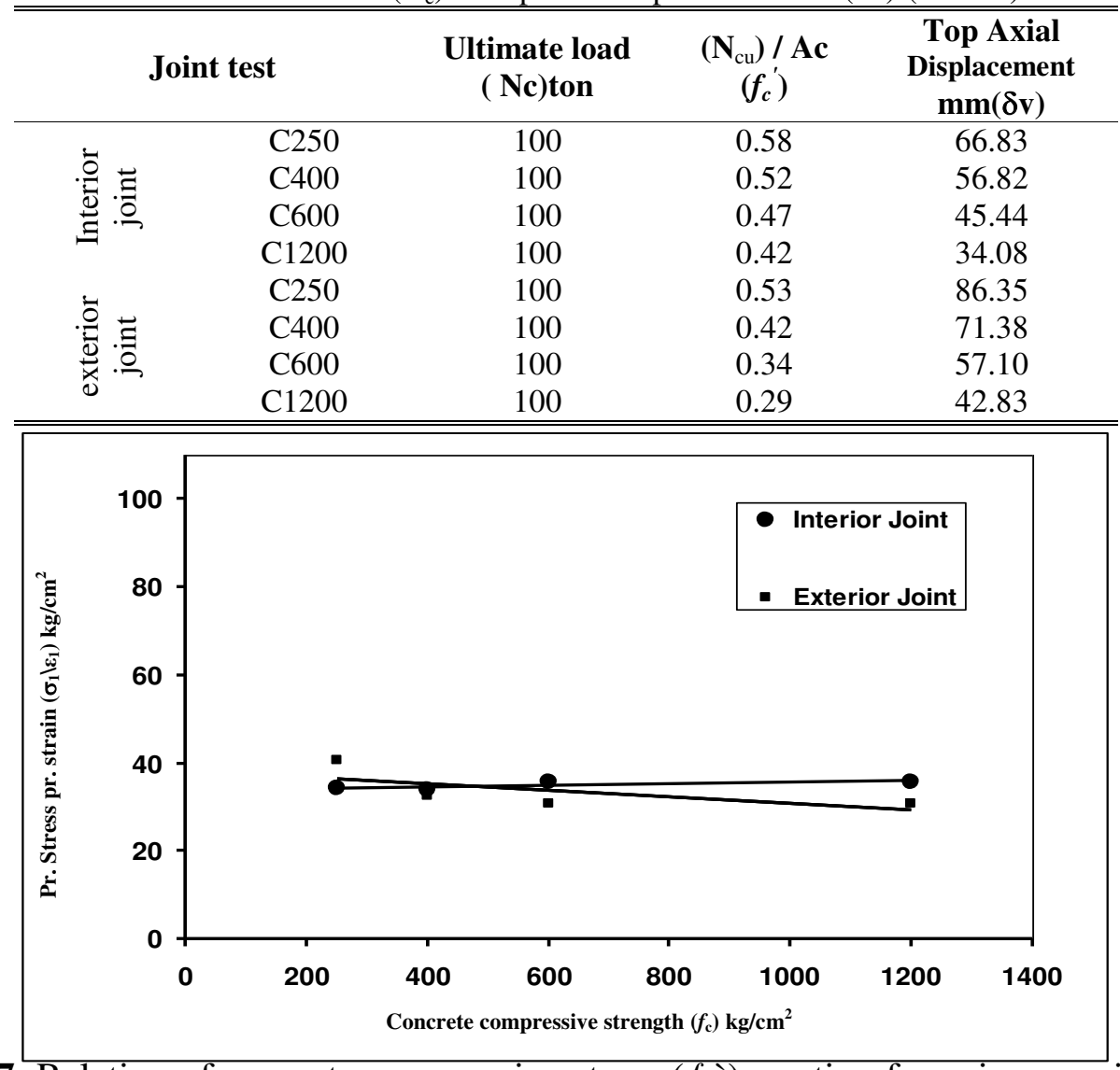

Fig.27. Relation of concrete compressive stress $\left(f_{\mathrm{c}}{ }^{\prime}\right)$ - ratio of maximum principle stress / maximum principle strain $\left(\sigma_{1} / \varepsilon_{1}\right)$ for studied joints

Journal of Engineering Sciences, Assiut University, Faculty of Engineering, Vol. 41, No. 2, March, 2013,E-mail address: jes@aun.edu.eg 
A. M. Ahmed et al, Static Behaviour of Different types of R.C Beam-Column Connections as Affected by Both Value of Acting Axial Normal Force and Grade of Used Concrete (Theoretical Study), pp. 321- 364

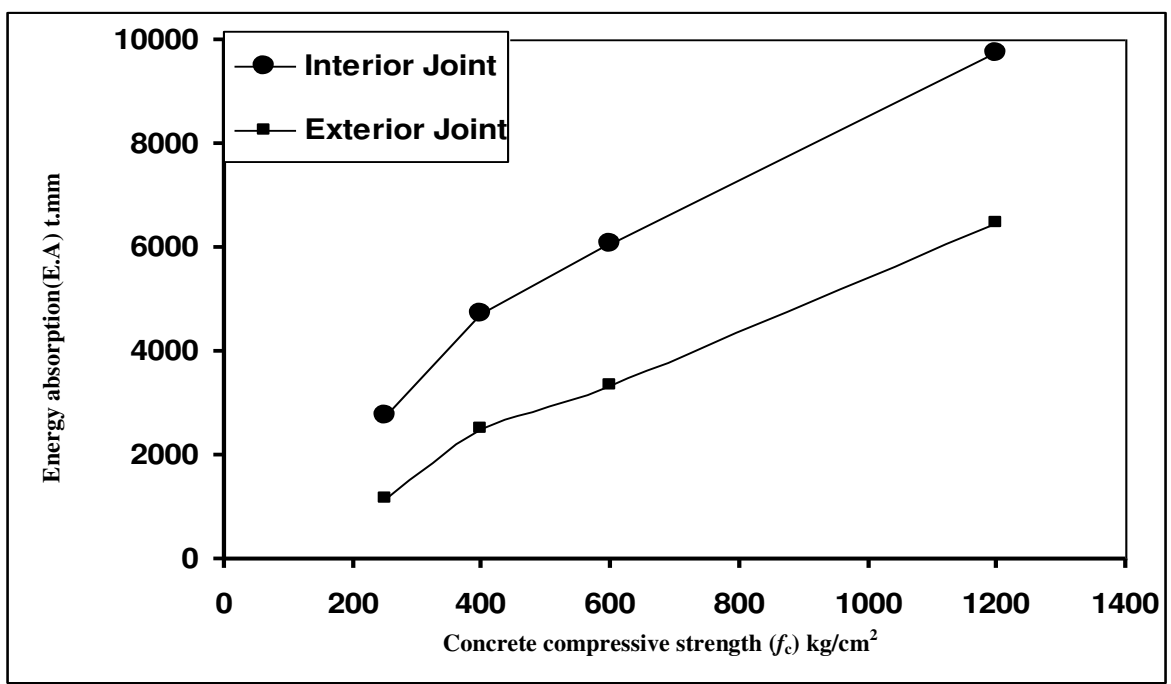

Fig.28. Relation of concrete compressive strength $\left(f_{c}^{\prime}\right)$ - energy absorption (E.A) for joints

\subsection{W.R.T energy absorption (E.A) point of view:}

The energy absorption capability of a beam-to-column connection may be evaluated as the area under the lateral load-deflection curve. At this case of loading it is interesting to note that, on the light of Figure 28 and Table 7, it is obvious that, as the compressive strength of used concrete increases, the dissipated energy considerably increases disregarding the type of joint. Meanwhile for a given concrete grade, the dissipated energy is higher for interior joint rather than that for exterior joint.

\subsection{W.R.T observed failure modes point of view:}

Failure Modes for Beam-Column Joints can be summarized as follows as shown in Figs.29 and 30:

(BF): Brittle failure: This occurs because of cracks that occur at the joint face, where the crack concrete burst when the load increased the compression, after the cracking of concrete, the axial pressure also makes the larger mechanical friction formed between the concrete blocks, if the axial pressure exceeds the critical value, the concrete will be crushed, and the shear strength will be reduced. (BF) mode of failure for interior and exterior joints were observed In J. $(4,9,11)$ and J. $(20,25,30)$ respectively.

(DF): Ductile failure :This failure occurs when the plastic hinges occurs at column either caused by compression force, in this case a lot of cracks can be seen in column failure. This condition can caused the frame to sway and hard to repair (DF) mode of failure for interior and exterior joints were observed in J. $(5,13,16)$ and J. $(27,32)$ respectively. 
A. M. Ahmed et al, Static Behaviour of Different types of R.C Beam-Column Connections as Affected by Both Value of Acting Axial Normal Force and Grade of Used Concrete (Theoretical Study), pp. 321- 364

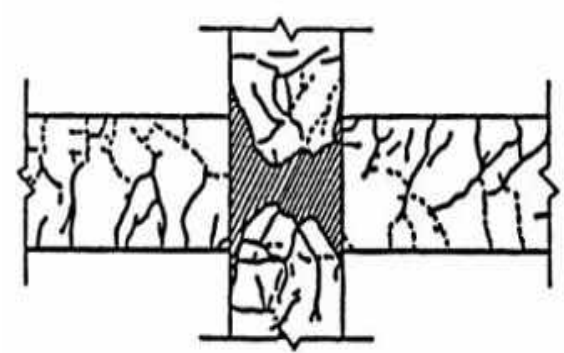

(DF)-mode (Kazuhiro K.Z.1991)

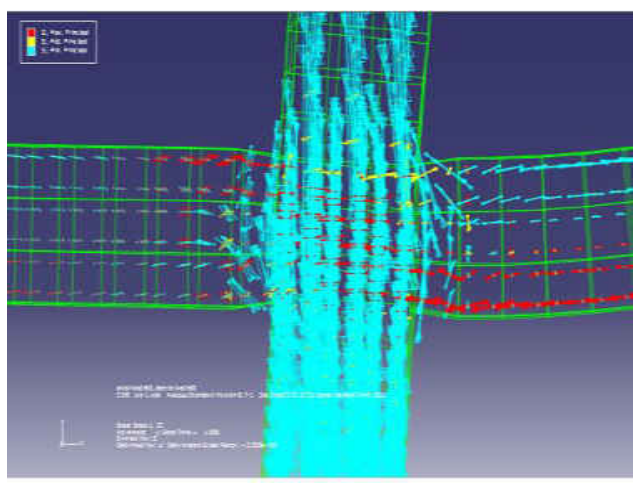

(DF)-mode Joint No.(16)-obtained results

Fig.29.a Deformation mode

$55 \mathrm{~S}$

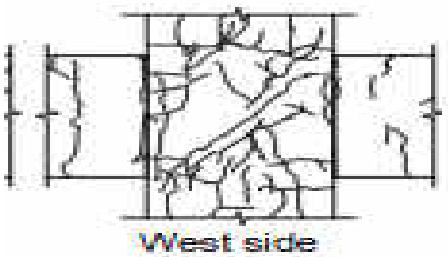

$55 \mathrm{~s}$

(BF)-mode (Fumio K.2004)

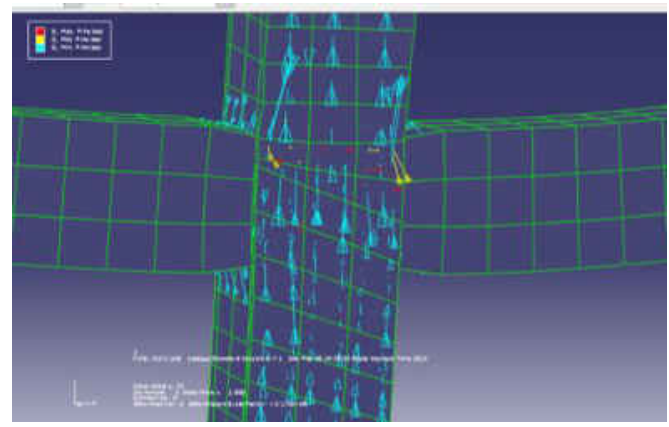

(BF)-mode Joint No.(4)-obtained results

Fig.29.b Deformation mode

Fig.29. Analytical crack patterns at final loading stage for interior beam-column joint

Journal of Engineering Sciences, Assiut University, Faculty of Engineering, Vol. 41, No. 2, March, 2013,E-mail address: jes@aun.edu.eg 
A. M. Ahmed et al, Static Behaviour of Different types of R.C Beam-Column Connections as Affected by Both Value of Acting Axial Normal Force and Grade of Used Concrete (Theoretical Study), pp. 321- 364

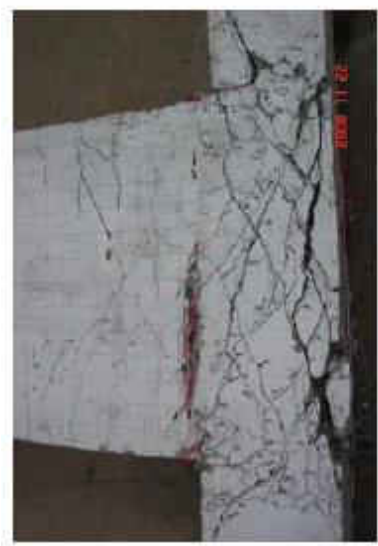

(DF)-mode (Xiaoli Yang 2009)

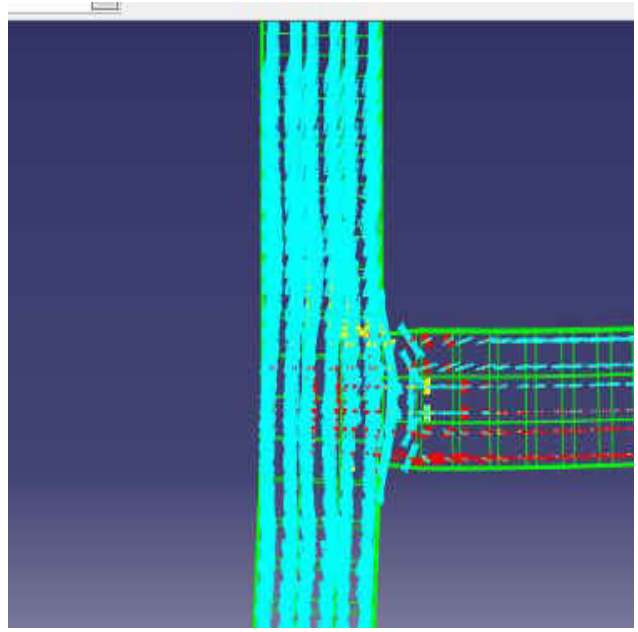

(DF)-mode Joint No.(32)-obtained results

Fig. 30.a Deformation mode

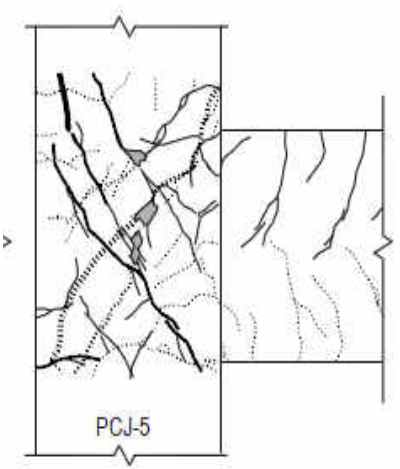

(BF)-mode (Hitoshi Sh. 2002)

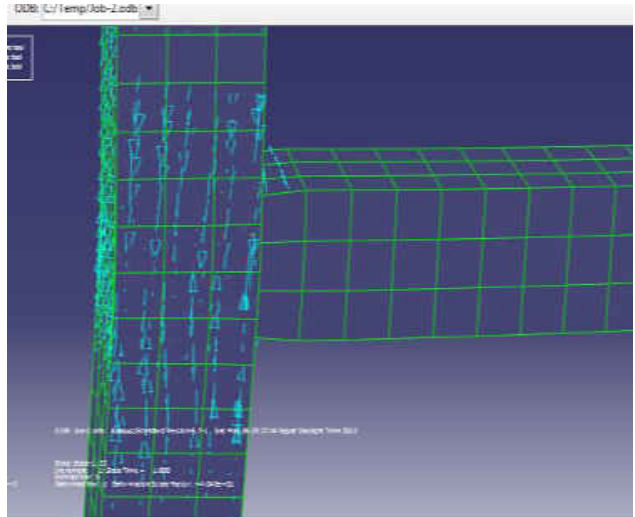

(BF)-mode Joint No.(20)-obtained results.

Fig. 30.b Deformation mode

Fig. 30. Analytical crack patterns at final loading stage for exterior beam-column joint

Journal of Engineering Sciences, Assiut University, Faculty of Engineering, Vol. 41, No. 2, March, 2013,E-mail address: jes@aun.edu.eg 
A. M. Ahmed et al, Static Behaviour of Different types of R.C Beam-Column Connections as Affected by Both Value of Acting Axial Normal Force and Grade of Used Concrete (Theoretical Study), pp. 321- 364

\subsection{Conclusions and recommendations}

The following conclusions are only valid for both interior and exterior joints where corner (knee) joint did not have variable axial column load.

\subsection{W.R.T loads and stresses point of view:}

\subsubsection{Column axial load:}

- The axial load ratio $\left(\mathrm{N}_{\mathrm{c}} / \mathrm{A}_{\mathrm{c}} f_{\mathrm{c}}\right)$ generally decreases with the increase of concrete compressive strength for the studied joints. Meanwhile, for a given grade of concrete, for interior joint the axial load ratio is bigger than that for exterior one by $131 \%$. This reflects the fact that the interior joint is more effective in resisting axial load compared with that for exterior joint.

\subsubsection{Joint shear stresses $\left(\tau_{J}\right)$ :}

- The joint shear stress $\left(\tau_{\mathrm{J}}\right)$ for interior joint is higher than that for exterior with $125 \%$. This means that the interior joint is considerably safe than the exterior joint.

- One of the findings of this study is that the joint strength coefficient, $(\gamma)$ defined by $\left(\gamma=\tau_{\mathrm{j}} / \checkmark f_{c}\right)$, changes with the variation of the column compressive axial load and mainly depends on the type of joint where, from comparing the results joint shear strength coefficient is given as average $\gamma=3.80$ for exterior joint of column axial load, and is given as average $\gamma=5.00$ for interior joint of column axial load.

- It is declared that the $\left(\tau_{\mathrm{j}} \mid \dot{f}_{\mathrm{c}}\right)$ mode strength decreases by increasing the grade of concrete $\left(\dot{f}_{\mathrm{c}}\right)$. Higher values were corresponding interior joints rather than that for exterior joints.

8.6.3. Bond Stress $\left(\mu_{\mathrm{b}}\right) \mathrm{kg} / \mathrm{cm}^{2}$ :

- For both interior and exterior joints, the increase of concrete grade is usually accompanied by an increase in the induced bond Strength $\left(\mu_{\mathrm{b}}\right)$.

$$
\frac{\mathrm{u}_{b}}{\sqrt{\mathrm{f}_{c}^{\prime}}}=k=\text { cons } \tan t
$$

where $(k)$ is a constant depends on both used grade of concrete and type of joint as well as case of loading.

- The increase of concrete grade is usually accompanied by a constant ratio for induced ratio of $\left(\tau_{\mathrm{j}} / \mu_{\mathrm{b}}\right)$ disregarding the type of joint. Also, it is interesting to note that Interior joint usually possess the same values of the induced ratio of $\left(\tau_{j} / \mu_{b}\right)$ for any grade of concrete.

- Suggested values of $(k)$ for calculating average bond capacity of RC joints at the following Table. 
A. M. Ahmed et al, Static Behaviour of Different types of R.C Beam-Column Connections as Affected by Both Value of Acting Axial Normal Force and Grade of Used Concrete (Theoretical Study), pp. 321- 364

\begin{tabular}{ccc}
\hline \hline \multirow{2}{*}{ Type of Joint } & \multicolumn{2}{c}{$(\boldsymbol{k})$ values of $\left(\boldsymbol{f}_{\boldsymbol{c}}^{\prime}\right)$} \\
& $\mathbf{C 2 5 0}$ and $\mathbf{C 4 0 0}$ & $\mathbf{C 6 0 0}$ and $\mathbf{C 1 2 0 0}$ \\
\hline Interior joint & 0.72 & 0.74 \\
Exterior joint & 0.54 & 0.56 \\
\hline \hline
\end{tabular}

\subsubsection{Axial principal stress $\left(\sigma_{1}\right) \mathrm{kg} / \mathrm{cm}^{2}$ :}

- The increase of concrete compressive strength is effective to increase the principle stresses and hence the increase of concrete grade is usually accompanied with a decrease in the induced ratio of $\left(\sigma_{1} / \dot{f}_{\mathrm{c}}\right)$ disregarding the type of joint. Also, it is interesting to note that interior joint usually posses higher values of the induced ratio of $\left(\sigma_{1} / f^{\prime}\right)$ for any grade of concrete.

\subsection{W.R.T deformations and strains:}

\subsubsection{Axial displacement $m m\left(\delta_{v}\right)$ :}

An axial displacement at different joint illustrated that vertical displacement increases with the decrease of compressive strength. Finally vertical displacement is bigger at exterior joint than of interior joint with $135 \%$.

\subsubsection{Axial strain $\left(\varepsilon_{1}\right) \mathrm{cm} / \mathrm{cm}$ :}

- Axial strain level is compared with the axial stress level for the various joints by concrete compressive strength for plane beam-column joints, where an increase of axial stress is usually followed by a corresponding increase of axial strain.

- It is also observed that Interior joint usually possess a higher values of maximum induced principle strains for any given grade of concrete.

- It is indicated that the increase of concrete grade $\left(f_{\mathrm{c}}{ }^{\prime}\right)$ is usually accompanied by constant rate of $\left(\sigma_{1} / \varepsilon_{1}\right)$ for interior joints, however a slight effect to decrease $\left(\sigma_{1} / \varepsilon_{1}\right)$ for exterior joint. Finally the both interior and exterior joints have the same value of induced ratio $\left(\sigma_{1} / \varepsilon_{1}\right)$ against the corresponding values of concrete compressive strength.

\subsection{W.R.T energy absorption (E.A):}

- It is interesting to note that, for this case of loading as the compressive strength of used concrete increases the dissipated energy considerably increases disregarding the type of joint. Meanwhile for a given concrete grade the dissipated energy is higher for interior joint rather than that for exterior joint.

\subsection{W.R.T observed failure mode:}

In this case of loading there are two types of modes of failure are observed namely:

\{BF $\}$ mode Brittle failure: In joints No. $\{\mathrm{J} .(4,9,11)\}$ for interior joints and as joints

No. $\{$ J. $(20,25,30)\}$ for exterior joints. 
A. M. Ahmed et al, Static Behaviour of Different types of R.C Beam-Column Connections as Affected by Both Value of Acting Axial Normal Force and Grade of Used Concrete (Theoretical Study), pp. 321- 364

\{DF $\}$ mode Ductile failure: In joints No. $\{$ J. $(5,13,16)\}$ for interior joints, and as joint No. J. $(27,32)$ for exterior joints.

\section{Recommendations}

The following topics can be recommended as subjects for future research studies.

1. To modify the joint failure at this case of loading an additional reinforcement can significantly enhance the strength and toughness gains of the confined concrete. The smaller tie spacing can also be provided at both upper and lower ends of the column to prevent concrete bursting at that particular location during the test.

2. High strength concrete when it is used in columns connection, needs large quantities of confining reinforcement to ensure ductile behavior, which can be provided by high strength transverse reinforcement. The spacing recommendation for confinement reinforcement from Comittee 352 appears to be valid for highstrength joints so that it is found that the high-strength concrete grades achieved higher levels of ductility, with better energy absorption and an increased initial stiffness in comparison to identically detailed normal strength for internal, external and knee specimens.

3. More experimental tests for RC beam-column connections are needed with specific conditions such as using headed bars or fiber reinforced concrete will be beneficial in the extension of understanding behavior of $\mathrm{RC}$ beam-column connections.

4. The suggested joint shear behavior model was constructed based on standard theoretical tests of RC beam-column connection subassemblies. Because the boundary conditions of RC beam-column connections are often different in real RC moment resisting frames (MRF), the effect of boundary conditions on joint shear behavior could be further investigated

5. Nonlinearity due to concrete spalling and reinforcement buckling has not been taken into account in the present analysis; hence it is needed further study.

6. More experimental tests are required to be taken into account the different section geometry of columns beams. It is suggested that circular columns may be designed in beam-column connections at the future investigation. 
A. M. Ahmed et al, Static Behaviour of Different types of R.C Beam-Column Connections as Affected by Both Value of Acting Axial Normal Force and Grade of Used Concrete (Theoretical Study), pp. 321- 364

\section{Nomenclature}

$A_{b} \quad$ Gross area of cross section of beam.

$\mathrm{A}_{\mathrm{g}}, \mathrm{A}_{\mathrm{c}} \quad$ Gross area of cross section of column.

$\mathrm{A}_{\mathrm{cs}} \quad$ Area of the column reinforcement.

$\mathrm{A}_{\mathrm{j}} \quad$ Horizontal sectional area of joint core.

$\mathrm{A}_{\mathrm{s} 1}, \mathrm{~A}_{\mathrm{s} 2} \quad$ Top and bottom reinforcements of beam respectively.

$\mathrm{A}_{\mathrm{st}} \quad$ The area of longitudinal reinforcement.

at Total area of tensile reinforcement.

ag Total area of longitudinal reinforcement.

aw Total area of web reinforcement placed between top and bottom beam bars.

$\mathrm{d}_{\mathrm{c},} \mathrm{d}_{\mathrm{b}} \quad$ Effective depth of beam, effective depth of column .

E.A Energy Absorption.

$E_{c} \quad$ The concrete static modulus.

Es The steel elastic modulus.

$\mathrm{E}_{0} \quad$ The plastic strain.

$f_{c}^{\prime} \quad$ Compressive cylinder strength of concrete.

$f_{\text {cu }} \quad$ The cube strength.

$f^{\prime}{ }_{t} \quad$ Concrete tensile strength.

$f_{\mathrm{y}} \quad$ Yield strength of steel reinforcement.

$\mathrm{H} \quad$ The total height of the columns above and below the joint.

$\mathrm{h}_{\mathrm{c}}, \mathrm{h}_{\mathrm{col}} \quad$ Depth of column.

$\mathrm{h}_{\mathrm{j}} \quad$ Effective depth of joint.

$L_{b}, L \quad$ Length of the beam right and left the joint.

$\mathrm{L}_{\mathrm{c}} \quad$ The heights of the columns above and below the joint.

$\mathrm{N}_{\mathrm{c}} \quad$ Axial column loads.

$N_{c u} \quad$ The ultimate axial column load obtained.

$N_{c c} \quad$ The cracking axial column load obtained.

$V_{c} \quad$ Column shear force.

$\gamma \quad$ The nominal strength coefficient.

$\delta_{\mathrm{v}} \quad$ Axial top displacement.

$\varepsilon_{1} \quad$ principal axial strains.

$\sigma_{1} \quad$ principal axial stress.

$\tau_{\mathrm{J}} \quad$ Joint shear stress.

$\rho_{w} \quad$ Joint shear reinforcement. 
A. M. Ahmed et al, Static Behaviour of Different types of R.C Beam-Column Connections as Affected by Both Value of Acting Axial Normal Force and Grade of Used Concrete (Theoretical Study), pp. 321- 364

\section{References}

[1] ABQUS, ABAQUS Theory Manual, (v6.7-1) (2002), Training Manual, (v6.51) (2004), User Manual, (v6.5-1) (2000).

[2] ACI 318M-02 (2002): "Building code requirements for structural concrete and commentary", Reported by ACI Committee 318, American Concrete Institute, Farmington Hills, Michigan.

[3] ACI-ASCE Committee 352 (1995): "Recommendations for Design of BeamColumn Joints in Monolithic Reinforced Concrete Structures" (AC1 352R-95), American Concrete Institute, Detroit, Michigan, 1995.

[4] British Standards Institution, BS8110 (1985): "Structural use of concrete", Part 1 Code of practice for design and construction, London, U.K.

[5] Beres, A., White, A.N., and Gergely, P. (1992): Seismic behavior of RC frame structures with on ductile details: Part I-Summary of experimental findings of full scale beam-column joint tests, Report NCEER-92-0024, NCEER, SUNY Buffalo, NY.

[6] Bing Li, Yiming Wu, and Tso-Chien Pan (2003): "Seismic Behavior of Non seismically Detailed interior Beam-Wide Column joints-Part2: Theoretical Comparisons and Analytical Studies" ACI Structural journal, V.100, No.1, January-February. 2003. PP.56-65.

[7] Building Seismic Safety Council (1997): FEMA 273: NEHRP Guidelines for the Seismic \Rehabilitation of Buildings. Federal Emergency Management Agency, Washington, DC.

[8] Chris P. Pantelides, Jon Hansen, Justin Nadauld and Lawrence D. Reaveley (2002): "Assessment of Reinforced Concrete Building Exterior Joints with Substandard Details" Pacific Earthquake Engineering Research Center College of Engineering University of California, Berkeley May 2002.

[9] EN 1998-1:2003, "General rules-specific rules for various materials and elements", Euro code 8: Design Provisions for Earthquake Resistant Structures.

[10]Filica Thin Ying Chik (2007): "Influence of Different Concrete Strength on The Behavior of Interior Reinforced Concrete Beam-Column Joint" Degree of master of civil Engineering University of Technology Malaysia, November 2007.

[11] Hakuto, S., Park, R. and Tanaka, H. (2000): "Seismic load tests on interior and exterior beam-column joints with substandard reinforcing details", ACI Structure. J., 97(1), PP.11-25.

[12] J. Lee and G. L. Fenves (1998): "Plastic-Damaged model for cycling loading of concrete structures", 124(8), Journal of Engineering Mechanics 21-40 Feb.2005.

[13] Kupfer, H., Hilsdorf, H.K., Rüsch, H. (2011): Behavior of Concrete under Biaxial Stress, Journal ACI, Proc. V.66, No.8, Aug., pp.656-666.

[14] Kurose, Y. (1987): "Recent studies on reinforced concrete beam column joints in Japan” PMFSEL Report No. 87-8 Department of Civil Engineering, University of Texas at Austin, Austin, TX.

[15] Kumar, S.R.S. B.V. and G.S.B., (2002): "Hysteretic behavior of lightly reinforced-concrete exterior beam-to-column joint sub-assemblages". J. Struc. Eng. SERC, 29 (1):31-37. 
A. M. Ahmed et al, Static Behaviour of Different types of R.C Beam-Column Connections as Affected by Both Value of Acting Axial Normal Force and Grade of Used Concrete (Theoretical Study), pp. 321- 364

[16] NZS 3101 (1995): "The design of concrete structures", Concrete Structures Standard, Part 1: Code of Practice, Part 2: Commentary, Standards New Zealand, Wellington, New Zealand, 256 pp \& 264 pp.

[17] Park R. and Paulay T. (1975): Reinforced Concrete Structures, John Wiley \& Sons, New York, USA, 769 pp.

[18] Paul S. Baglin and Richard H. Scott (2000): "Finite Element Modeling of Reinforced concrete Beam- Column Connections." ACI Structural journal, V.97, No.6, November-December. 2000 PP. 886-894

[19] Sam Lee (2008): "Nonlinear Dynamic Earthquake Analysis of Skyscrapers" Guangzhou Scientific Computing Consultants Co. Ltd, 507/140 Dong fang Xi Rd, Guangzhou 510170, 7 China, szslee@gmail.com CTBUH 8th World Congress, Dubai, 3-5 March 2008

[20] S. R. Uma and Sudhir K. Jain (2006): "Seismic design of beam-column joints in RC moment resisting frames - Review of codes "Structural Engineering and Mechanics, Vol. 23, No. 5 (2006) 579-597 579N Department of Civil Engineering, Indian Institute of Technology, University of Canterbury, New Zealand.

[21] Xiaoli Yang, Guoliang Bai and Hongxing Li (2009): "Study on Design Method of SRC Abnormal Exterior Joint of Large-scale Thermal Power Plant Frame-bent Structure", School of Civil Engineering, Xi'an University of Architecture and Technology China Vol. 3, No. 9 Modern Applied Science Sep. 2009. 
A. M. Ahmed et al, Static Behaviour of Different types of R.C Beam-Column Connections as Affected by Both Value of Acting Axial Normal Force and Grade of Used Concrete (Theoretical Study), pp. 321- 364

" السلوك الاستاتيكي للانواع المختلفة من الوصلات الخرسانية المسلحة بين الكمرة والعمود تحث

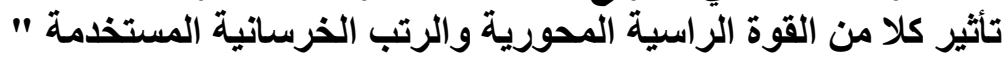
( دراسة نظرية)

ملخص:

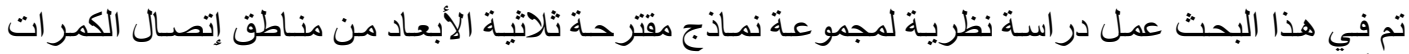

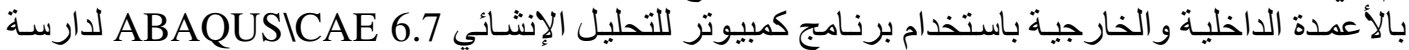

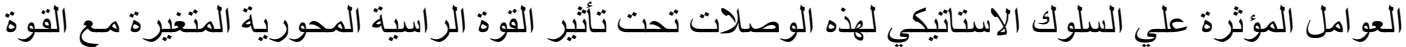

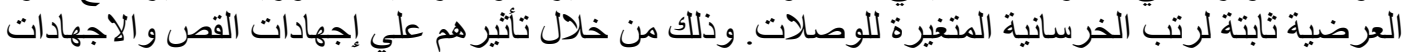

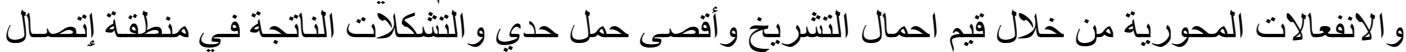

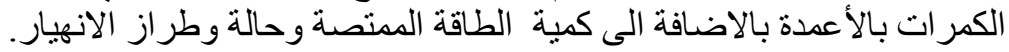

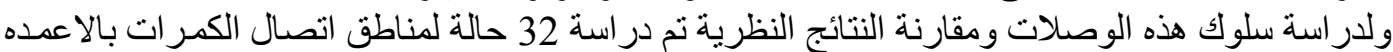

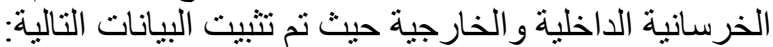

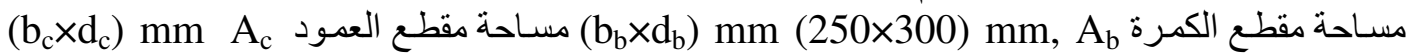
مسـاحة حديد (H×L)m (2.0×3.0) m, A A مساحة منطقة الاتصـال الكمرة بـالعمود (300×300mm)

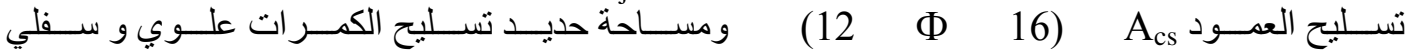

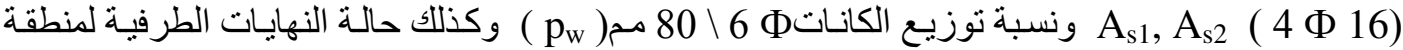

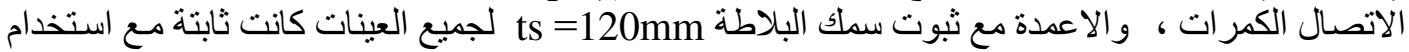

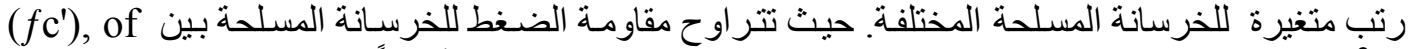
رئ kg/cm²,

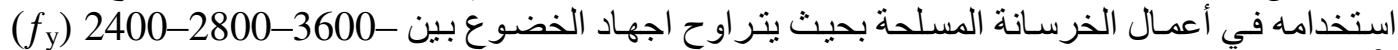
العب 4000 kg/cm²

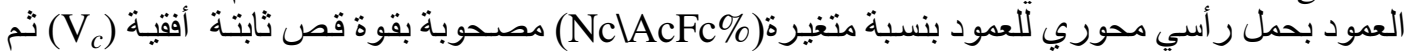

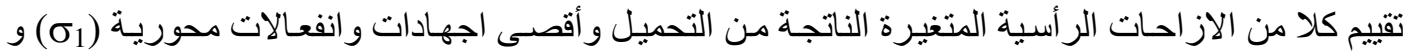

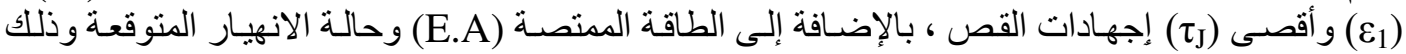

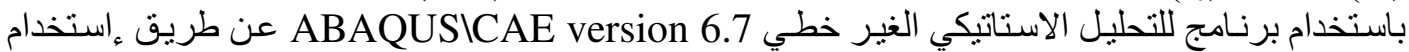

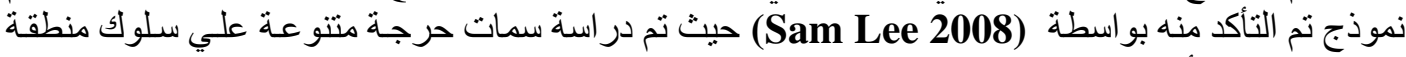

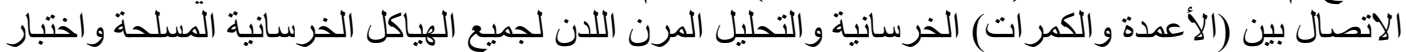

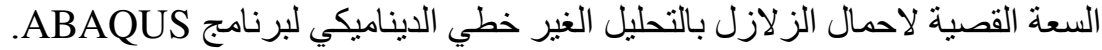

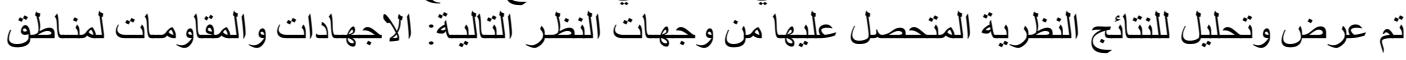

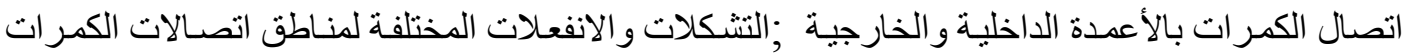

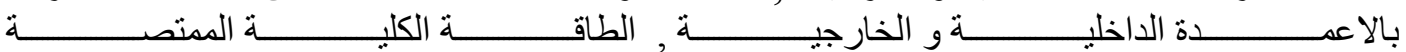
(E.A) ( (DF). (BF) ( $\left.\mathrm{N}_{\mathrm{cc}}\right)$;

التوصيات:

1- لزيادة قدرة وسعة تحمل الوصسلات ولتطوير انهيـار منساطق اتصـال الكمر ات بالأعمدة بلززم اضـافة حديد

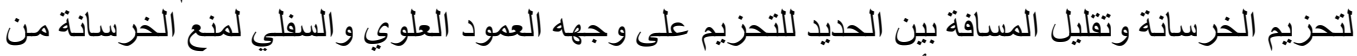

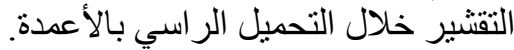

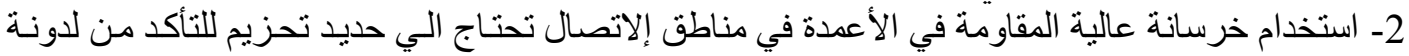

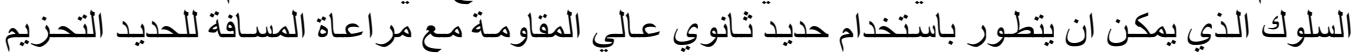

Journal of Engineering Sciences, Assiut University, Faculty of Engineering, Vol. 41, No. 2, March, 2013,E-mail address: jes@aun.edu.eg 
A. M. Ahmed et al, Static Behaviour of Different types of R.C Beam-Column Connections as Affected by Both Value of Acting Axial Normal Force and Grade of Used Concrete (Theoretical Study), pp. 321- 364

لاعطاء لدونة عالية وزيادة في الطاقة الممتصة مع متانة عالية بالمقارنـة باستخدام مقاومـة عاديـة لمنـاطق الاتصال الداخلية و الخار جية والية والركنية.

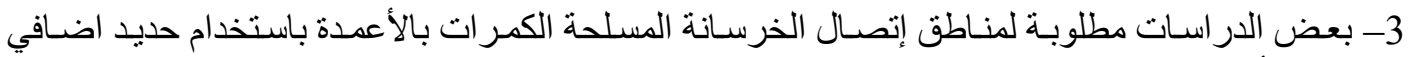

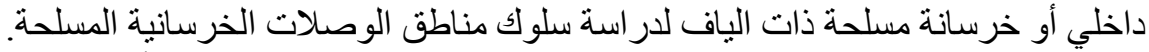

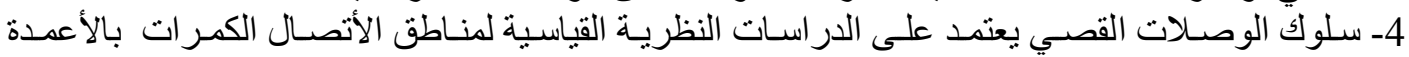

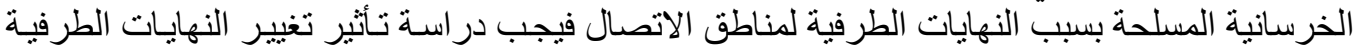
لمناطق الاتصال.

5ـالأخذ في الاعتبار التحليل الغير خطي عند تقنشير الخرسانة وحدوث انحنـاء حيث ان ذلك غير مـأخوذ في

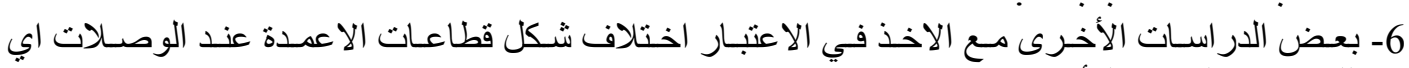
للقطاعات الدائرية للأعمدة يجب مبع در استها. 